Spring 2002

\title{
Toward a Great Sioux Nation Judicial Support Center and Supreme Court: An Interim Planning and Recommendation Report for the Wakpa Sica Historical Society's Reconciliation Place Project
}

John P. LaVelle

University of New Mexico - School of Law

Frank Pommersheim

University of South Dakota School of Law

Follow this and additional works at: https://digitalrepository.unm.edu/law_facultyscholarship

Part of the Indian and Aboriginal Law Commons

\section{Recommended Citation}

John P. LaVelle \& Frank Pommersheim, Toward a Great Sioux Nation Judicial Support Center and Supreme Court: An Interim Planning and Recommendation Report for the Wakpa Sica Historical Society's Reconciliation Place Project, 17 Wicazo Sa Review 183 (2002).

Available at: https://digitalrepository.unm.edu/law_facultyscholarship/668

This Article is brought to you for free and open access by the UNM School of Law at UNM Digital Repository. It has been accepted for inclusion in Faculty Scholarship by an authorized administrator of UNM Digital Repository. For more information, please contact amywinter@unm.edu, Isloane@salud.unm.edu,sarahrk@unm.edu.

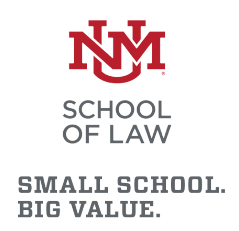

SMALL SCHOOL.
BIG VALUE. 


\section{Toward a Great Sioux Nation Judicial Support Center and Supreme Court An Interim Planning and Recommendation Report for the Wakpa Sica Historical Society's Reconciliation Place Project}

Frank Pommersbeim and Jobn P. LaVelle

This Interim Planning and Recommendation Report describes the significance and potential benefits of the Wakpa Sica Historical Society's Reconciliation Place Project in its endeavor to facilitate the establishment of a Great Sioux Nation Supreme Court. The report emphasizes that the vision of establishing such a Court has existed among the Sioux tribes of South Dakota, North Dakota, and Nebraska for generations and that the project's legitimacy and ultimate success depend on its ability to continue fostering the tribes' endorsement of and participation in the Court's development and implementation.

$\mathrm{T}$

he report highlights the need for strengthening the existing tribal judicial systems in the project region as a necessary and highly desirable step toward establishing the Great Sioux Nation Supreme Court. Areas in which support are needed include access to legal research, publication of tribal court opinions, the availability of "law clerks" for conducting legal research, and increased training of tribal judges, clerks, administrators, prosecutors, public defenders, and practicing counsel. The report also provides a broad overview of legal issues facing tribal 
courts. These issues include the persistence of historic principles of federal Indian law supporting tribes' inherent sovereignty, the impact of modern Supreme Court decisions on the scope of tribes' criminal and civil jurisdiction in Indian country, the importance of the tribal court exhaustion doctrine in leveraging respect for the work of tribal courts, and a number of specific and complex cutting-edge issues that tribes are currently confronting and will continue to grapple with in the future.

The report strongly recommends immediately instituting a Great Sioux Nation Judicial Support Center as a prerequisite for establishing the Great Sioux Nation Supreme Court. The Center would consist of a number of crucial components, including an Indian law library, an Indian law research component, a tribal law and culture journal, a legislative drafting project, a constitution revision project, and an economic development project. The report emphasizes that a strong and permanent Great Sioux Nation Judicial Support Center would function as the indispensable infrastructure for manifesting the vision of a Great Sioux Nation Supreme Court.

Finally, the report addresses a number of crucial issues concerning the ultimate establishment of the Court itself. These issues include the Court's composition in terms of participating tribes, the Court's relationship with existing tribal appellate courts, the qualifications and selection of justices, the Court's enabling legislation and judicial rules, the Court's jurisdiction, the governing law to be applied by the Court, and enforcement of the Court's judgments.

The Wakpa Sica Historical Society's Reconciliation Place Project has the potential of making an enormous and lasting contribution to the strengthening of tribal sovereignty. The project's regional and cultural focus comprises a truly innovative approach to supporting the heroic efforts of Indian tribes to endure and prosper as strong, selfgoverning indigenous nations. The authors of this report are honored to have participated in envisioning and elaborating the concrete steps that must be taken to make the present dream of a Great Sioux Nation Supreme Court a future reality for the constituent Lakota, Dakota, and Nakota nations.

\section{N T R O D U C T I O N}

The Wakpa Sica Historical Society's Reconciliation Place Project is a wide-ranging undertaking that envisions establishing a physical structure in Fort Pierre, South Dakota, a historical trading site for members of the Great Sioux Nation and various non-Indian traders and commercial interests, and a significant site in the journeys of Lewis and Clark. The project regards the location as neutral but historically significant. Various intended components of this effort include establishment of a 
reconciliation place, a repatriation center, a museum, and assistance in establishing a Great Sioux Nation Supreme Court.

The Historical Society has received an exploratory "planning" grant from the United States Justice Department to develop more thorough analysis and recommendations concerning the merits, details, and viability of the various efforts listed above. This report focuses on issues and recommendations concerning the Great Sioux Nation Supreme Court component.

The concept of a Great Sioux Nation Supreme Court certainly does not originate with the Wakpa Sica Historical Society. Rather, it is an idea or vision that has existed within the Great Sioux Nation for generations that the Society fully recognizes and supports. It is rare, for example, to engage in conversation with tribal people about tribal courts and justice in which the concept of a Great Sioux Nation Supreme Court does not soon come into play. Yet until recently there has been very little in-depth discussion of the theoretical and practical issues surrounding the establishment of a Great Sioux Nation Supreme Court. ${ }^{1}$

This report is designed to provide a historical and contemporary context for the project, which includes a needs assessment of tribal courts within South Dakota, North Dakota, and Nebraska, a summary of legal issues facing tribal courts, discussion of the establishment of a Great Sioux Nation Judicial Support Center as the necessary infrastructure supporting the capstone work of establishing the Great Sioux Nation Supreme Court, and discussion of the issues surrounding the establishment of the Great Sioux Nation Supreme Court itself.

The report is designed to provide a basis for continuing discussion and implementation of the project, including elements to assist the project in achieving legitimacy, maintaining longevity, and enhancing impact within the Great Sioux Nation. Many projectsjudicial and otherwise- have come and gone within Sioux country because they lacked legitimacy and vision. As noted above, vision for such a project already exists within the Great Sioux Nation. Legitimacy can flow only from full tribal understanding, endorsement, and active participation in the development and implementation of the Great Sioux Nation Supreme Court. Formation of the Court involves an act of (collective) tribal sovereignty and therefore cannot be imposed regardless of the Historical Society's good will or depth of funding.

The Wakpa Sica Historical Society's Reconciliation Project has great potential, but only if it can "walk the talk" of its proposal with integrity, patience, and insight and if it fully understands its role as partner and facilitator and not owner or controller of the project itself. To date, the Wakpa Sica Historical Society has clearly demonstrated its willingness and ability to embrace these kinds of operating principles. In order to advance this potential, the report will provide both a 
description of the relevant issues as well as recommendations concerning how to deal with these specific principles, remembering all the while that the tribes of the Great Sioux Nation are the heart and soul of what is possible in this significant undertaking.

\section{NEEDS ASSESSMENT OF TRIBALCOURTS I N S U TH DAKOTA, NORTH DAKOTA, A N D N E B R A S K A}

While it goes without saying that tribal courts both nationwide and within the project region have significant unmet needs, it is important not to forget their rapid growth in competence and maturity within the last twenty-five years. This is a fact that has been recognized by many scholars and practitioners within the field. ${ }^{2}$ In fact it is often this very reality of rapid growth that has created new needs that both local and national units of government have not been able to keep up with or even, in some cases, to adequately understand.

The needs identified herein flow from the expertise and experience of the authors of the report and accompanying survey ${ }^{3}$ and of members of the relevant tribal judiciaries as shared with the authors in ongoing discussions. These needs are not prioritized but are particularized to the tribal courts within the region. Needs assessments can often be bloated and generic because they often have no contextual or experiential grounding. That is not the case in this instance.

As this section on needs assessment makes clear, at least implicitly, there is a necessity to address some of the issues concerning current tribal courts in order to ensure that there is a firm infrastructure on which to graft a Great Sioux Nation Supreme Court. To ignore the infrastructure question is to invite failure and disappointment. The recommendations to address these "needs" are found in a later section of this report. ${ }^{4}$

\section{Improved Access to Legal Research}

A primary element in the making of quality legal decisions at both the trial and appellate levels is the capacity to perform the necessary legal research with which to resolve the issues raised by the case. Judges in both the state and federal context rely extensively on the work of their clerks. This need has not been ameliorated by the advent of computerized research, which might "speed up" research but does nothing to parse the cases and to synthesize what the cases mean and how they fit together. As a result, tribal courts are often doubly disadvantaged. They have no consistent computerized access to the ever-expanding raw material of decision making (cases, statutes, legislative history, administrative rules, etc.) and generally no access to the synthesizing 
hand of a law clerk to digest, organize, summarize, and integrate the relevant research.

As a result of these shortcomings, and consonant with the most conventional of wisdoms, tribal courts need consistent access to legal research as is available through the LEXIS and Westlaw electronic databases. Yet even here there are unique Indian law problems because the critical resource of tribal court opinions is not yet consistently available on-line. This wave of the present (not future) threatens to bypass or barely touch many tribal courts. Tribal courts therefore require the hardware, software, and training to go with computerized research. It is also true, however, that many other tribal law resources such as treaties, constitutions, and codes are not available on-line, and thus print libraries also must be maintained.

This is, however, a necessary but not sufficient condition for tribal judges to develop research parity with their state and federal colleagues. The danger here is to assume that a technological fix is all that is needed, that research is technology. It is not. Technology generates the raw material of meaningful research, but it takes a law clerk, a person with some sense of craft, to refine these raw materials into a more usable and malleable form for judges to actually use.

In a related vein, technology and computer programming are necessary ingredients to develop consistently coherent case files and case management systems. An essential element of the administration of justice is just that: the ability to manage individual cases and the docket as a whole in an expeditious and efficient manner ("Justice delayed is justice denied," etc.). Yet there also needs to be a similar recognition that cases are ultimately not administered by computers but by individuals who require the necessary training, recompense, and recognition to provide equity and to avoid the problems that often result in chronic turnover at the critical case management and administrative level. Court clerks and administrative personnel are vital cogs in the wheels of justice, and meeting their needs is key to enhancing the functioning of this often overlooked and underappreciated sector of tribal courts.

\section{Systematic Publication of Tribal Court Opinions}

The raw legal data of many tribal court judicial decisions are the cases and precedents of other tribal courts, particularly other tribal courts in the region. Given the relative youth of many tribal courts a considerable number of their decisions involve cases of first impression. The decisions of other tribal courts in similar matters therefore become a crucial ingredient and adjunct in the making of many tribal court decisions.

Currently, much of this jurisprudential base is not available to tribal courts. The only national reporter of tribal court decisions is the 
Indian Law Reporter, a publication of the American Indian Resources Institute/American Indian Lawyer Training Program in Oakland, California. This reporter is in the nature of a monthly looseleaf service that is not available on-line and is quite expensive. Few, if any, tribal courts in the project region maintain a current subscription.

One response to this shortcoming would be the development of a Great Sioux Nation Law Reporter to reprint all the decisions-both trial and appellate- of the courts of constituent tribal participants in the Great Sioux Nation Supreme Court. Such a reporter could be issued in print on a quarterly basis and made available on-line weekly. The on-line publication could be one of several offerings to be found at a Great Sioux Nation Judicial Support Center Web page fully describing the scope of the project and related services. ${ }^{5}$

The establishment of an effective reporter-both print and electronic - would have the collateral benefits of making such decisions available to others nationally and outside the region as well as advancing the legitimacy of the overall program because of its delivery of important services in a timely and regular manner just like similar activities in the state and federal judicial systems. Since there is often a paucity of available precedent, such publication efforts will fill a significant void. And in order to do this effectively, print and technology must be in a complementary relationship. The work-product of any court is its decisions, and such an important work-product needs to circulate quickly and effectively. Without such a dedicated effort, the courts might appear inefficient and prone to excessive delay. Such a reporter would also be an invaluable resource to attorneys preparing to appear before these courts.

\section{Availability of "Law Clerks" to Perform Legal Research}

As discussed above, improved legal research is not the product of a simple technological fix but requires a law-trained individual not only to assist in the doing of the research but also to organize, describe, and synthesize the research for the applicable judge or panel of judges. Legal research in this context also includes the capacity of such an individual to assist and participate in the other potential projects described below 6 relative to legislative drafting, constitutional review, and economic development. In the absence of such an individual or individuals, this exciting project is likely to be static rather than dynamic, constrictive rather than expansive, and pedestrian rather than innovative.

Legal research is more than the generation of information. It requires interaction with a trained human and legal intelligence to put that information in a useful and usable context. Regardless of potential cost, the need for law clerks is essential. Much of this legal research 
could be performed by University of South Dakota and University of North Dakota law students on a supervised and compensated basis as a valuable legal and intern experience. Such internships would provide unique opportunities for law students to contribute to and learn about tribal courts and the field of Indian law.

This need is underscored by the extensive caseloads that face most tribal courts. ${ }^{7}$ These exceptionally high caseloads put a very high premium on the time of tribal judges. The pressure to hear and decide cases in order to advance and manage the judicial docket efficiently is immense, and not surprisingly it greatly reduces the time available to judges to do legal research. In these circumstances, access to a law clerk to do research is a twofold gift. It is likely to enhance the quality of justice rendered in a particular case and to improve the quality of justice across the entire system because of greater efficiency in the administration of justice.

\section{Increased Training of All Tribal Court Sectors}

Training is an absolute necessity in order to continue to advance the development of tribal courts. Training is required in all sectors: judges, clerks/administrators, prosecutors/public defenders, and members of the private and tribal bar. This need for training can be divided roughly into two components: one is a component related to the uniqueness of tribal courts and Indian law, a specialized kind of continuing legal education (CLE) approach; and the other is the related issue relative to working for and in a developing tribal institution seeking to advance competence and efficiency but with a sense of cultural continuity.

Tribal judges. Indian law is increasingly a field of rapid and complex development. ${ }^{8}$ These changes often have profound implications for tribal court jurisdiction as well as the attendant governing law. In addition there is often an increased demand for the development and application of tribal common law. Given the rapidity and significance of these legal developments, training for tribal judges to help keep them abreast in CLE fashion in these areas of law is critical to ensuring the continuation of legally reliable decision making.

It is also true that tribal trial judges continue to need training in the context of improving their skills in handling trials with or without juries. This is important for several reasons, including expanding caseloads, expanding complexity of cases tried in tribal trial courts, and delivering procedural (as opposed to substantive) equity. This kind of training is particularly relevant for the non-law-trained members of the tribal judiciary.

There is also the need for training to assist tribal judges—at both the trial and appellate level-to improve and enhance their ability to write thoughtful and cogent legal opinions to explain and justify their 
decisions. Such efforts, for example, might reduce the likelihood of appeal in that a fair number of current tribal court appeals are filed simply because there is no adequate explanation of the trial court's decision. This training also knits together with the availability of law clerks to establish a research base from which tribal judges can craft well-written decisions.

Another cultural — though seldom articulated—benefit of training is the opportunity of the judges themselves to share insight and frustration and to develop a sense of community as people serving the individual tribes of the Great Sioux Nation. A sense of community and collegiality are essential elements in forging an enduring and committed tribal judiciary.

Clerks and court administrators. Training of clerks and court administrators is no less essential to the well-being and advancement of tribal courts. With increasing caseloads and stature as well, the demand on clerks to maintain accurate and concise file records (both manually and electronically) will become increasingly pressing. And while training at this level has been overlooked and underappreciated, any judge or practitioner knows it is the clerks who are the glue that holds the system together.

Court administrators are also under the gun as a result of expanding caseloads and outside scrutiny to ensure and improve the flow of tribal dockets in order to maintain and enhance the administration of justice within Indian country. This training needs to be able to respond to both the systems that remain essentially manual in nature and those that are electronically managed in whole or in part. Individuals in these situations need training in the context of not only what their current case management systems are but also what they are likely to be in the future, especially in the likely transfer and transition from manual to electronic and computer-based models.

Tribal prosecutors and public defenders. Again, the obvious: any person serving as prosecutor or public defender has a tremendous responsibility in the pursuit of justice within the tribal criminal justice system. As the numbers indicate, the overwhelming bulk of most tribal court dockets is taken up with criminal matters, and therefore training of prosecutors and public defenders must be a central component. This is especially true when a moderate to significant number of tribal prosecutors are still not formally law-trained. It is also to be noted that for those tribes that do not have public defender systems such training (on the defense side) should be made available to any individual — whether law-trained or not-who does criminal defense work within the tribal court system.

Given the raw fact that personal liberty is at stake in criminal proceedings and that the right to counsel guarantee in the Indian Civil Rights Act of 1968 is not mandatory on the tribes, ${ }^{9}$ the utmost in train- 
ing needs in this area should be made a priority and preference. Prosecution and defense work is labor intensive, and therefore training, both procedural and substantive, as well as case management assistance are central to maintaining due process and respect for individual liberty.

Private counsel who practice in tribal court. As noted in many areas throughout this report, the practice of Indian law, especially in tribal courts, is both unique and subject to rapid change. This fact points to the necessity of training based on the CLE model in state and federal settings for practitioners who practice regularly in tribal court. All courts—but particularly tribal courts—are substantially affected by the quality and expertise of the practicing bar. Therefore it is incumbent upon tribes to provide CLE opportunities for their practitioners.

The delivery of these programs is best administered through tribal bar associations where they exist, ${ }^{10}$ but in their absence (which is the norm), they must be provided by the tribal courts themselves. This training needs to focus — as it does in the state and federal context—on new developments in the law, especially Indian law in its broadest meaning and the local law of the particular tribe. Changes in Indian law are often wide-sweeping and need to be understood and responded to with dispatch.

All of these training needs require money, and because many tribes, especially in the project area, are not economically flush, the provision of outside funding to meet these needs is pivotal. In complementary fashion, it is worth noting that salary levels are generally low in all tribal court sectors, particularly at the clerk and administrator level, and there needs to be attention focused on salary (and benefits) concerns as critical dimensions relative to improving staffing stability and continuity. Such funding and budgetary matters may be addressed in a detailed fashion in a subsequent report upon direction of the Historical Society and the participating tribes.

\section{E G A I I S U E S FACING TRIBAL COURTS}

Since 1970, when President Nixon announced a groundbreaking federal executive policy supporting tribal self-determination, ${ }^{11}$ Indian tribes throughout the United States have exercised their inherent sovereign powers of self-government with increasing determination, consistency and innovation. This modern surge in tribal efforts at "doing sovereignty $^{\prime \prime 2}$ has resulted in a dramatic proliferation and refinement of tribal judicial systems, and has spurred congressional action lending additional support for the maintenance and development of tribal courts. ${ }^{13}$ Today, Indian tribes and the federal government alike recognize that strengthening tribal judicial systems is crucial for ensuring the survival of Indian tribes as sovereign nations and for facilitating the general health, well-being, and prosperity of tribal communities. 
Running parallel to this encouraging tribal-federal collaboration in the development of strong and sophisticated tribal judicial systems are unprecedented, countervailing changes in the doctrines of federal Indian law emerging from recent decisions of the United States Supreme Court. These decisions have been criticized as "signaling a dramatic retreat from the Court's historic role as protector of the rights of Indian tribes under the Constitution, laws, and treaties of the United States, and as a function of inherent tribal sovereignty."14 Because of these decisions, Indian tribes, in seizing the opportunities for broad exercise of their inherent sovereign powers, must also be wary of the limitations on the exercise of tribal powers imposed by the Supreme Court. What follows is a summary of the increasingly complex contours of federal Indian law impacting the exercise of tribal courts' adjudicatory powers.

\section{Historic Principles of Indian Law Affecting Tribal Court Jurisdiction in Indian Country}

Like tribal governmental powers generally, tribal court adjudicatory authority derives ultimately from the inherent sovereignty of Indian tribes as self-governing indigenous nations whose origins predate the establishment of the United States government and the colonization of the American continents by European forces..$^{15}$ In three landmark cases of the early nineteenth century, the Supreme Court under the leadership of Chief Justice John Marshall established a number of core principles governing the field of federal Indian law.

In Jobuson v. M'Intosh (1823), the Court held that Indian tribes' inherent sovereign powers, as constrained under United States law, do not include the power to alienate tribal lands without the consent of the United States. ${ }^{16}$ The Court reasoned that as a consequence of the "discovery" of Indian lands by European powers, the United States as successor to those "discovering" nations holds "ultimate title" to Indian lands, with Indian tribes retaining a "right of occupancy." 17 In Cherokee Nation v. Georgia (1831), the Court held that Indian tribes are not "foreign states" for purposes of the Constitution's conferral of Supreme Court original jurisdiction over suits between states and "foreign states." ${ }^{18}$ The Court suggested that instead of meriting the label "foreign states," Indian tribes "may, more correctly, perhaps, be denominated domestic dependent nations.... Their relation to the United States resembles that of a ward to his guardian." ${ }^{19}$ And in Worcester v. Georgia (1832), the Court firmly rebuffed an effort by the State of Georgia to annihilate the sovereignty of the Cherokee Nation by forcing the application of Georgia's laws within federally protected Cherokee country. ${ }^{20}$ The Court declared:

The Cherokee nation ... is a distinct community, occupying its own territory, with boundaries accurately described, 
in which the laws of Georgia can have no force. . . The whole intercourse between the United States and this nation, is, by our constitution and laws, vested in the government of the United States. ${ }^{21}$

Altogether, these foundational cases establish the following core propositions of federal Indian law: (1) Indian tribes, though not "foreign states," are sovereign nations; ${ }^{22}$ (2) Indian tribes may not exercise specific sovereign powers that compromise the territorial security of the United States ${ }_{i}{ }^{23}$ (3) the United States has a general obligation to protect, defend, and support Indian tribes, as the tribes' "guardian" ${ }_{i}{ }^{24}$ and (4) tribal sovereignty is absolutely protected under the Constitution, laws, and treaties of the United States from invasion and dispossession by the states. ${ }^{25}$

In the late nineteenth century a new, additional principle began emerging from the Supreme Court's Indian law decisions that, like the principles from the Marshall Trilogy, has profoundly affected the exercise of inherent tribal sovereignty: the principle of congressional "plenary power" in Indian affairs. In United States v. Kagama (1886), the Court affirmed the power of Congress to vest jurisdiction over serious felonies committed on Indian reservations in the federal courts, thereby depriving Indian tribes of a substantial portion of their inherent sovereign authority to prosecute offenders. ${ }^{26}$ Although the Court intimated that broad congressional authority over Indians "is necessary to their protection,"27 it is clear that the Kagama Court viewed congressional power in Indian affairs as broader than what fairly can be inferred from the Marshall Court's principles of federal recognition of tribes as sovereign nations, national territorial security-based limitations on inherent tribal sovereignty, the federal-tribal trust relationship, and protection of tribes from assertions of dominion by the states. Indeed, so expansive was the Kagama Court's vision of congressional power in Indian affairs that the Court refused to confine that power to any particular provision of the Constitution, ${ }^{28}$ and distorted the Marshall Trilogy to deny any constraint on congressional power discernible in those foundational cases. ${ }^{29}$

Although steeped in error and incompatible with the Marshall principles, Kagama's novel assertion of sweeping congressional power over Indians soon became an entrenched part of the Supreme Court's Indian law jurisprudence. Indeed, in Lone Wolf $v$. Hitchcock (1903), ${ }^{30}$ the Court stretched this newly invented "doctrine" to the point of practically subverting the Marshall Trilogy's core concern about federal protection of Indian rights. In Lone Wolf, the Court refused to review the legality of Congress's decision to abrogate the Medicine Lodge Treaty with the Kiowa, Comanche, and Apache Tribes by forcibly opening the tribes' reservation to white settlers despite the treaty's express requirement of tribal consent. ${ }^{31}$ The Court stated: 
When, therefore, treaties were entered into between the United States and a tribe of Indians it was never doubted that the power to abrogate existed in Congress. ...

... If injury was occasioned . . by the use made by

Congress of its power, relief must be sought by an appeal to that body for redress and not to the courts. ${ }^{32}$

Lone Wolf's suggestion that the exercise of congressional power in Indian affairs is exempt from judicial review has been modified by subsequent doctrinal developments. ${ }^{33}$ However, the central theme of expansive congressional power in Indian affairs pervading both Kagama and Lone Wolf has emerged as a fundamental principle of the field of federal Indian law.

In synthesizing the disparate historic principles defining the field, Felix S. Coben's Handbook of Federal Indian Law observes:

Perhaps the most basic principle of all Indian law, supported by a host of decisions, is that those powers which are lawfully vested in an Indian tribe are not, in general, delegated powers granted by express acts of Congress, but rather "inherent powers of a limited sovereignty which has never been extinguished." 34

The core proposition that Indian tribes possess all inherent sovereign powers that have not been "extinguished" is the essential starting point for understanding the convoluted contours of tribal adjudicatory authority declared by the modern Supreme Court. As amplified below, many of the modern Supreme Court's restrictions on tribes' inherent power to adjudicate are at odds with the fundamental Indian law principles articulated in the Marshall Trilogy and supplemented by the congressional plenary power doctrine. Indeed, a number of prominent Indian law scholars have suggested that these decisions are a disturbing result of the modern Court's failure to appreciate the meaning and significance of the Court's own historic Indian law principles and to apply these principles in addressing disputes involving the exercise of Indian rights. ${ }^{35}$ To the extent that these decisions are thus the result of error, they may comprise only a temporary repression of inherent tribal adjudicatory power under United States law.

\section{Scope of Tribal Court Criminal Jurisdiction in Indian Country}

In light of core principles of Indian law, a sovereign Indian tribe theoretically has inherent power to prosecute criminal offenders within the tribe's territory unless (1) such power has been limited or "extinguished" 
in the exercise of Congress's "plenary power" in Indian affairs, or (2) the exercise of such power compromises or threatens the territorial security of the United States. As mentioned previously, Congress effectively diminished tribes' inherent power to adjudicate a number of serious felonies committed in Indian country when Congress enacted the 1885 Major Crimes Act, a statute upheld by the Supreme Court in Kagama v. United States. ${ }^{36}$

In 1978, the modern Supreme Court began departing dramatically from fundamental principles when the Court addressed the scope of a tribe's inherent power to exercise criminal jurisdiction over nonIndians. In Oliphant v. Suquamish Tribe, the Court held that "Indian tribes do not have inherent jurisdiction to try and to punish non-Indians." 37 Writing for the majority, then-Justice Rehnquist refused to ground the Court's denial of tribal criminal adjudicatory power over non-Indians in either the congressional plenary power doctrine or the Marshall Trilogy's national territorial security limitation on inherent tribal sovereignty. Instead, Rehnquist announced a broad new theory of "judicially made Indian law"38 for limiting inherent tribal authority: the socalled implicit divestiture theory. ${ }^{39}$ Under this new theory, "Indian tribes are prohibited from exercising both those powers of autonomous states that are expressly terminated by Congress and those powers 'inconsistent with their status. " 40

Thus, the Olipbant Court transmogrified the Marshall Court's national territorial security-based limitation on inherent tribal sovereignty into an expansive theory for stripping tribes of inherent sovereign power based on the Court's own impressions and projections concerning the tribes' inferior "status." Dubiously purporting to discern evidence that historically "Congress shared the view of the Executive Branch and the lower federal courts that Indian tribal courts were without jurisdiction to try non-Indians," the Oliphant Court concluded that because of their inferior "status," Indian tribes have no criminal jurisdiction over non-Indians. ${ }^{41}$

In 1990, the Supreme Court invoked Oliphant's "implicit divestiture" theory to deprive Indian tribes of inherent power to exercise criminal jurisdiction over "nonmember Indians," i.e., Indians who are members of tribes other than the forum tribe. In Duro v. Reina, the Court held that "Indian tribes lack [criminal] jurisdiction over persons who are not tribe members." 42 Conceding that evidence of a past federal assumption that Indian tribes lack criminal jurisdiction over nonmember Indians was "somewhat less illuminating than in Oliphant," 43 the Court nevertheless asserted its belief that the exercise of such jurisdiction was irreconcilable with the "the tribes' status as limited sovereigns." 44 As in Oliphant, the Court in Duro thus defied the Marshall Trilogy's overriding concern about ensuring plenary protection of Indian rights under federal law and instead used the occasion of the Duro dispute to give 
expression to the Court's own conviction-evoking the racially derogatory assumptions underlying the discredited "discovery" doctrine ${ }^{45}$ that Indian tribes are inherently inferior.

Responding to the Supreme Court's erroneous analysis and holding in Duro, Congress overrode that decision in 1991 by expressly recognizing and affirming Indian tribes' inherent authority to exercise criminal jurisdiction over all Indians in Indian country, regardless of the particular tribal membership of Indian defendants. ${ }^{46}$ In the course of this legislation's enactment, the Committee of Conference explained that it was "clarifying an inherent right which tribal governments have always held and was never questioned until . . Duro. . . . The Congressional power to correct the Court's misinterpretation is manifest as is its plenary power over Indian tribes, which derives from the Constitution." 47

In view of the Major Crimes Act, Oliphant, Duro, and the Durocorrecting legislation, Indian tribes today retain their inherent sovereign power to exercise misdemeanor criminal jurisdiction over all Indians in Indian country. ${ }^{48}$ The most prominent issue facing tribal courts with respect to this retained criminal jurisdictional authority is how best to exercise it without exciting additional efforts by the current activist Supreme Court to strip tribes of this crucial attribute of inherent sovereignty.

\section{Scope of Tribal Court Civil Jurisdiction in Indian Country}

Theoretically, the scope of an Indian tribe's inherent civil adjudicatory power under federal law is determined according to the same historic parameters defining the scope of tribes' inherent criminal adjudicatory power: the Marshall Trilogy principles supplemented by the congressional plenary power doctrine. Despite the Supreme Court's embrace of a doubtful theory comparable to "implicit divestiture" in post-Oliphant cases addressing the scope of tribes' inherent civil legislative authority in Indian country, ${ }^{49}$ several cases decided before and after Olipbant indicated the Court's recognition that tribes' inherent civil adjudicatory authority in Indian country is broad, in keeping with the Marshall principles and subject only to narrowly construed limitations expressly imposed by Congress.

In Williams v. Lee (1959), for example, the Supreme Court invalidated an attempt by an Arizona court to adjudicate a civil action brought by a non-Indian plaintiff against Navajo citizens for an alleged breach of contract occurring within the boundaries of the Navajo Reservation. ${ }^{50}$ Although the Court posited that Worcester's "broad principles" protecting Indian tribes from state incursions in Indian country had been "modified . . . in cases where essential tribal relations were not involved and where the rights of Indians would not be jeopardized," it 
concluded that "to allow the exercise of state jurisdiction here would undermine the authority of the tribal courts over Reservation affairs and hence would infringe on the right of the Indians to govern themselves."51

In another pre-Oliphant case, Fisher v. District Court (1976), ${ }^{52}$ the Court again endorsed the inherent power of Indian tribes to exercise civil jurisdiction in Indian country. Fisher addressed the question of whether a Montana court had "jurisdiction over an adoption proceeding in which all parties are members of the [Northern Cheyenne] Tribe and residents of the ... Reservation." ${ }^{53}$ The Supreme Court held that the state court had no such jurisdiction. The Court reasoned that the exercise of jurisdiction by the state court would infringe " $[\mathrm{t}]$ he right of the ... Tribe to govern itself independently of state law" in violation of the tribal sovereignty-affirming rule of Williams $v$. Lee and in contravention of federal statutes protecting the Tribe's right of self-government. ${ }^{54}$ The Court held that "[s]ince the adoption proceeding is appropriately characterized as litigation arising on the Indian reservation, the jurisdiction of the Tribal Court is exclusive." ${ }^{55}$ Williams and Fisher both indicate that prior to Oliphant, the Supreme Court manifested its obligation to protect the sovereignty of Indian tribes by recognizing and affirming tribes' broad inherent powers to exercise civil adjudicatory authority in Indian country.

This trend of Supreme Court recognition of tribes' broad inherent civil adjudicatory powers continued after Oliphant as well. For instance, two months after Oliphant stripped tribes of inherent criminal jurisdiction over non-Indians, the Court rendered another decision supportive of tribes' inherent civil adjudicatory power and harmonious with foundational principles of Indian law. In Santa Clara Pueblo v. Martinez (1978), the Court narrowly construed the 1968 Indian Civil Rights Act's grant of federal court remedial authority, thus minimizing ICRA's intrusion into the sovereign domain of tribal courts. ${ }^{56}$ In concluding that ICRA does not give rise to implied injunctive or declaratory civil remedies other than habeas corpus enforceable against Indian tribes or tribal officials in federal court, ${ }^{57}$ the Court stated:

Creation of a federal cause of action for the enforcement of rights created in Title I [of ICRA] . . . plainly would be at odds with the congressional goal of protecting tribal selfgovernment. Not only would it undermine the authority of tribal forums, but it would also impose serious financial burdens on already "financially disadvantaged" tribes.

... Tribal forums are available to vindicate rights created by the ICRA. ... Tribal courts have repeatedly been recognized as appropriate forums for the exclusive adjudication of disputes affecting important personal and property interests of both Indians and non-Indians. ${ }^{58}$ 
The Court offered similar endorsements of tribes' civil adjudicatory authority in the post-Oliphant decisions of National Farmers Union Insurance Cos. v. Crow Tribe (1985) $)^{59}$ and Iowa Mutual Insurance Co. v. LaPlante (1987). ${ }^{60}$ In National Farmers, the Court unanimously held that with respect to a civil claim brought in tribal court, challengers to the tribe's jurisdiction must exhaust their remedies in tribal court before being permitted to assert a federal common law question in federal court about the limits of the tribe's jurisdiction. ${ }^{61}$ The Court squarely rejected the argument that Indian tribes lack inherent civil power over nonIndians by force of Olipbant's fiat depriving tribes of inherent criminal power over non-Indians:

$[\mathrm{T}]$ he question whether a tribal court has the power to exercise civil subject-matter jurisdiction over non-Indians in a case of this kind is not automatically foreclosed, as an extension of Oliphant would require. Rather, the existence and extent of a tribal court's jurisdiction will require a careful examination of tribal sovereignty, the extent to which that sovereignty has been altered, divested, or diminished, as well as a detailed study of relevant statutes, Executive Branch policy as embodied in treaties and elsewhere, and administrative or judicial decisions.

We believe that examination should be conducted in the first instance in the Tribal Court itself. ${ }^{62}$

The Supreme Court again demonstrated respect for the exercise of tribes' inherent civil adjudicatory powers in Iowa Mutual Insurance Co. v. LaPlante. ${ }^{63}$ In Iowa Mutual, the Court clarified that the tribal court exhaustion requirement announced in National Farmers applies even where the challenger to the tribal court's jurisdiction seeks federal judicial review based on a federal court's diversity jurisdiction rather than federalquestion jurisdiction. ${ }^{64}$ The Court supported this holding with a strong affirmation of tribes' broad inherent civil adjudicatory powers in Indian country: "Tribal authority over the activities of non-Indians on reservation lands is an important part of tribal sovereignty. Civil jurisdiction over such activities presumptively lies in the tribal courts unless affirmatively limited by a specific treaty provision or federal statute."65 Significantly, the Iowa Mutual Court did not list "implicit divestiture" as one of the means by which tribes' inherent civil adjudicatory powers could be "affirmatively limited," suggesting that the Court regarded such powers as unaffected by the Oliphant line of cases.

These multiple signals in cases decided before and after Oliphant suggested that despite the modern Court's imposition of unprecedented limitations on the scope of tribes' inherent criminal and legislative powers, tribes' civil adjudicatory powers remained broad, consistent with 
fundamental principles of Indian law. However, in 1997, the Court imparted a decidedly contrary signal. In Strate v. A-1 Contractors, the Court unanimously held that the Three Affiliated Tribes of the Fort Berthold Indian Reservation had no inherent power to adjudicate a civil dispute between non-Indians stemming from an automobile accident occurring on a highway maintained by the State of North Dakota and passing across the reservation pursuant to a federally granted right-ofway. ${ }^{66}$ The Court stated that "tribal courts may not entertain claims against nonmembers arising out of accidents on state highways, absent a statute or treaty authorizing the tribe to govern the conduct of nonmembers on the highway in question." 67

In reaching this result, the Court rejected the argument of the tribes and the United States as amicus curiae that the principle of National Farmers and Iowa Mutual deferential to tribal court jurisdiction, and not the countervailing Oliphant line of cases, controls an inquiry into the scope of tribes' inherent civil adjudicatory authority ${ }^{68}$ Instead, the Court insisted, even with respect to the question of the scope of inherent civil adjudicatory powers, tribes are subject to Oliphant's "status"based "implicit divestiture" rule as extended to cases addressing tribes' inherent civil legislative powers in "the pathmarking case" 69 of Montana v. United States. ${ }^{70}$ After thus expanding Montana's main rule-that "the inherent sovereign powers of an Indian tribe do not extend to the activities of nonmembers of the tribe" ${ }^{\prime \prime 1}$ to cover tribal adjudicatory power in addition to tribal legislative power, the Court went on to further extend Montana to jurisdictional questions involving conduct on federally granted rights-of-way in addition to conduct on non-Indian-owned fee lands within reservation boundaries. ${ }^{72}$

Finally, in ultimately depriving the Three Affiliated Tribes of their inherent judicial authority, the Strate Court drastically narrowed the scope of Montana's crucial exceptions, which permitted tribal civil jurisdiction within reservation boundaries over (1) "activities of nonmembers who enter consensual relationships with the tribe or its members" and (2) conduct of nonmembers that "threatens or has some direct effect on the political integrity, the economic security, or the health or welfare of the tribe." ${ }^{\prime 73}$ Conceding the fact that the defendant in the tribal court suit, A-1 Contractors, indeed bad "enter[ed] [a] consensual relationship[ ] with the tribe or its members," the Strate Court nevertheless refused to acknowledge the applicability of Montana's first exception, opining that " $[t]$ he dispute ... is 'distinctly non-tribal in nature.'"74

In similar fashion, the Strate Court refused to recognize the applicability of Montana's second exception. Conceding, again, that "[u]ndoubtedly, those who drive carelessly on a public highway running through a reservation endanger all in the vicinity, and surely jeopardize the safety of tribal members," 75 the Court nevertheless narrowed Montana's second exception to cases in which the exercise of tribal jurisdiction is 
"necessary to protect tribal self-government." ${ }^{\text {76 }}$ Asserting without analysis that "[n]either regulatory nor adjudicatory authority over the state highway accident is necessary to preserve 'the right of reservation Indians to make their own laws and be ruled by them,'" the Court concluded that "[ $\mathrm{t}]$ he Montana rule, therefore, and not its exceptions, applies to this case."77

With its overreaching dictate of "judicially made Indian law"78 in Strate curtailing the scope of tribes' inherent civil adjudicatory authority, the Supreme Court defied the foundational principles of Indian law and the Court's own numerous precedents broadly supporting the jurisdiction of tribal courts. ${ }^{79}$ Moreover, to the extent the Strate Court attempted to make its dubious "status"-based common law mandate repressing tribal sovereignty apply to the exercise of tribes' civil adjudicatory authority over nonmember Indians as well as non-Indians-a purported exercise of federal judicial power of doubtful constitutional validity in any event ${ }^{80}$ — the Court further defied the tribal sovereigntyaffirming position of Congress vis-à-vis nonmember Indians as reflected in the Duro-correcting legislation of 1991 recognizing the inherent criminal jurisdiction of Indian tribes over nonmember Indians ${ }^{81}$ and overriding the Supreme Court's erroneous contrary impressions in Duro v. Reina. ${ }^{82}$ Strate thus stands out as an example of the Rehnquist Court's tendency to displace Congress's historic policymaking role in Indian affairs with a constitutionally suspect brand of judicial "legislation" of the Court's own creation.

Because of Strate's embrace of Oliphant's marauding "implicit divestiture" theory, Indian tribes in exercising their adjudicatory powers must be wary of the possibility that the Rehnquist Court will continue eroding those powers in future cases. Strate appears to have reversed the presumption in favor of tribal court civil jurisdiction over nonIndians in Indian country as stated in Iowa Mutual and discernible in other pre-Strate cases. ${ }^{83}$ After Strate, a tribe presumably has no civil legislative or adjudicatory jurisdiction over the conduct of non-Indians on non-Indian-owned fee lands or state highways within reservation boundaries. The tribe may rebut this presumption only by successfully invoking either of the Montana exceptions as narrowed by Strate, or by locating an affirmative congressional delegation of governmental authority by treaty or statute. ${ }^{84}$ The tribe retains its inherent civil legislative and adjudicatory authority over the conduct of tribal members, however, and arguably of nonmember Indians as well. ${ }^{85}$

\section{Loss of Tribal Court Jurisdiction as a Result of the "Shrinking" of Indian Country}

In addition to repressing Indian tribes' criminal and civil jurisdiction by expanding the antitribal "implicit divestiture" theory first deployed in 
1978 in Oliphant, the Supreme Court has further impounded tribes' inherent sovereign powers by interpreting congressional statutes bearing on the territorial extent of "Indian country" in a manner adverse to the protection of tribes' rights and thus inconsistent with foundational principles of Indian law. "Indian country" has a precise definition in the United States Code:

[T] he term "Indian country" . . means (a) all land within the limits of any Indian reservation under the jurisdiction of the United States Government, notwithstanding the issuance of any patent, and including rights-of-way running through the reservation, (b) all dependent Indian communities within the borders of the United States whether within the original or subsequently acquired territory thereof, and whether within or without the limits of a state, and (c) all Indian allotments, the Indian titles to which have not been extinguished, including rights-of-way running through the same. ${ }^{86}$

As explained in Felix S. Coben's Handbook of Federal Indian Law, federal recognition of an area as "Indian country" is critical because "[ $t$ ]ribes exercise substantial governing powers in their territory, they have important economic and property rights, and a number of federal laws also govern other relationships, all to the exclusion of state law." ${ }^{\text {"87 }}$ By interpreting "Indian country" narrowly in contravention of longstanding canons of construction deferential to the congressional policy of protecting Indian rights, the modern Supreme Court effectively has implemented an antithetical judicial policy of eroding Indian rights for the benefit of the states.

A prominent illustration of the Supreme Court's policy of "shrinking" Indian country under the guise of statutory interpretation is the Court's activism in expanding and deploying the judicial doctrine of the diminishment/disestablishment of Indian reservations. Beginning in 1975 with DeCoteau v. District County Court, 88 the Court has dramatically reduced the sovereign jurisdiction of a number of tribes-most of them in South Dakota-by concluding that "surplus land" statutes of the late nineteenth century and early twentieth century conveyed a clear congressional intent to diminish or "disestablish" the tribes' respective reservations.

In DeCoteau, the Court held that an 1891 Act of Congress stating that "[t]he Sisseton and Wahpeton bands of Dakota or Sioux Indians hereby cede, sell, relinquish, and covey" to the United States all the unallotted lands within the boundaries of the Lake Traverse Indian Reservation for "the sum of [ $\$ 2.50]$ per acre" thereby expressed Congress's clear intent also to eliminate the reservation altogether. ${ }^{89}$ The Court 
effected this wholesale destruction of the Sisseton-Wahpeton Sioux Tribe's territorial sovereignty despite the fact that in the 1891 Act "[ $t]$ here is not a word to suggest that the boundaries of the reservation were altered." 90 The Court refused to apply "the rule by which legal ambiguities are resolved to the benefit of Indians," asserting that "[a] canon of construction is not a license to disregard clear expressions of tribal and congressional intent." ${ }^{\prime 91}$

As Justice Douglas explained in dissent, "[t]he dimensions of the tragedy inflicted by [the DeCoteau] decision" were enormous. ${ }^{92}$ The decision immediately produced a " 'crazy quilt' or 'checkerboard' jurisdiction [that] defeats the right of tribal self-government guaranteed by [treaty]" by confining the territorial reach of the tribe's sovereign powers to Indian-owned allotments interspersed throughout the former boundaries of the "disestablished" reservation. ${ }^{93}$ Equally disturbing was the Court's creation of an unprincipled precedent for expediting the destruction of tribal sovereignty by interpreting turn-of-the-century "surplus land" statutes silent with respect to reservation boundaries as bespeaking Congress's intent to eliminate or diminish those boundaries. Hence, since 1975, the Court has employed and expanded its corrosive diminishment/disestablishment doctrine to drastically reduce the size of the Rosebud Reservation in South Dakota, the Uintah Valley Reservation in Utah, and, most recently, the Yankton Sioux Reservation in South Dakota. ${ }^{94}$

This pattern of decisions indicates the enormity of the threat to Indian tribes stemming from the modern Supreme Court's unprincipled approach to the issue of tribal sovereignty and jurisdiction in Indian country. The diminishment/disestablishment decisions demonstrate that the Court's defiance of inherent tribal sovereignty is not confined to erroneous common law opinions like Oliphant, Duro, Montana, and Strate but infuses cases of statutory interpretation as well. As mentioned previously, the Court accomplishes this restriction of inherent tribal sovereignty in cases of statutory interpretation by refusing to apply the long-standing Indian law canons of construction, which reflect the presumptive good faith of Congress in dealing with Indian tribes and Indian people-a good faith required by fundamental principles of Indian law. ${ }^{95}$ Thus, Justice Blackmun observed in his dissenting opinion in Hagen v. Utab (1994), "Although the [Court] purports to apply these [Indian law] canons in principle, it ignores them in practice, resolving every ambiguity in the statutory language, legislative history, and surrounding circumstances in favor of the State."96

Because the Rehnquist Court shows no signs of desiring to bring its cases construing "Indian country" in line with fundamental principles of Indian law, tribes must be cognizant of the momentous issue of territorial sovereignty at stake in every exercise of tribal jurisdiction entailing a determination of reservation boundaries. ${ }^{97}$ This caveat would 
seem especially pressing with respect to a tribal court's exercise of jurisdiction over any dispute arising from a transaction or occurrence taking place on land that a party alleges to be no longer part of "Indian country."

\section{Tribal Court Exhaustion Doctrine}

Although the Supreme Court in Strate narrowed the earlier decisions of National Farmers and Iowa Mutual recognizing tribes' broad civil adjudicatory authority over non-Indians in Indian country, ${ }^{98}$ the Strate Court also reaffirmed the continuing general efficacy of the tribal court exhaustion rule upheld in those earlier cases. ${ }^{99}$ In National Farmers, the Court explained the importance of the exhaustion rule:

Our cases have often recognized that Congress is committed to a policy of supporting tribal self-government and self-determination. That policy favors a rule that will provide the forum whose jurisdiction is being challenged the first opportunity to evaluate the factual and legal bases for the challenge. Moreover, the orderly administration of justice in the federal courts will be served by allowing a full record to be developed in the Tribal Court before either the merits or any question concerning appropriate relief is addressed. .. . Exhaustion of tribal court remedies ... will encourage tribal courts to explain to the parties the precise basis for accepting jurisdiction, and will also provide other courts with the benefit of their expertise in such matters in the event of further judicial review. ${ }^{100}$

The Supreme Court offered a similar endorsement of the requirement that parties exhaust tribal court civil remedies in Iowa Mutual:

Regardless of the basis for jurisdiction, the federal policy supporting tribal self-government directs a federal court to stay its hand in order to give a tribal court a "full opportunity to determine its own jurisdiction." In diversity cases, as well as federal-question cases, unconditional access to the federal forum would place it in direct competition with the tribal courts, thereby impairing the latter's authority over reservation affairs. Adjudication of such matters by any nontribal court also infringes upon tribal lawmaking authority, because tribal courts are best qualified to interpret and apply tribal law.

... [ [P]roper respect for tribal legal institutions requires that they be given a "full opportunity" to consider 
the issues before them and "to rectify any errors." The federal policy of promoting tribal self-government encompasses the development of the entire tribal court system, including appellate courts. At a minimum, exhaustion of tribal remedies means that tribal appellate courts must have the opportunity to review the determinations of the lower tribal courts. ${ }^{101}$

In Strate, the Court insisted that the tribal court exhaustion requirement of National Farmers and Iowa Mutual is "a prudential exhaustion rule, in deference to the capacity of tribal courts to 'explain to the parties the precise basis for accepting [or rejecting] jurisdiction."'102 While the Strate Court made this remark in rejecting the tribal petitioner's argument that the "status"-based "implicit divestiture" theory of Oliphant as expanded to tribes' civil legislative authority in Montana does not apply to tribes' civil adjudicatory powers, ${ }^{103}$ this dictum nevertheless shows that the Court continues to regard noninterference with tribes' adjudicatory processes as crucial to the fulfillment of the federal "policy of supporting tribal self-government and self-determination." 104

The Supreme Court created a narrow yet doctrinally troubling exception to the tribal court exhaustion rule in the recent case of $E l$ Paso Natural Gas Co. v. Neztsosie (1999). ${ }^{105}$ Neztsosie addressed the issue of whether a federal court must abstain, pursuant to the tribal court exhaustion rule, from deciding whether tribal common law claims brought initially in tribal court and alleging injuries caused by on-reservation corporate uranium mining operations qualify as federal "nuclear tort" causes of action under the Price-Anderson Act. ${ }^{106}$ Determining whether the tribal court claims were Price-Anderson "nuclear tort" claims, on the one hand, or non-Price-Anderson (i.e., strictly tribal common law) claims, on the other, was crucial in Neztsosie because of the federal district court's nonappealed holding that the tribal court had subject matter jurisdiction over the latter but not the former. ${ }^{107}$ The Supreme Court held that because a case raising the question of whether a legal claim is a Price-Anderson "nuclear tort" claim would be subject to removal as a matter of right if brought in state court, a federal court should not abstain from resolving this question, in deference to tribal court exhaustion, when the question is implicated in parallel proceedings initiated previously in tribal court. ${ }^{108}$

On one level, the tediously technical Neztsosie decision makes only a very minor intrusion into the tribal court exhaustion doctrine. The Supreme Court itself stressed the narrowness of this "Neztsosie exception" to the exhaustion rule, underscoring the Price-Anderson Act's "unusual preemption provision" that "transforms into a federal action 'any public liability action arising out of or resulting from a nuclear incident.'"109 Indeed, the Court suggested that "the existence of a federal 
preemption defense [to the exercise of tribal jurisdiction] in the more usual sense" would not require a reviewing federal court to suspend application of the tribal court exhaustion requirement. ${ }^{110}$ The Court explained:
Under normal circumstances, tribal courts, like state courts, can and do decide questions of federal law, and there is no reason to think that questions of federal pre- emption are any different. The situation here is the rare one in which statutory provisions for conversion of state claims to federal ones and removal to federal courts ex- press congressional preference for a federal forum..$^{111}$

In view of this careful qualification of the Court's decision not to apply the exhaustion rule and the Court's further endorsement of the "prudential requirement of tribal exhaustion,"112 the Neztsosie exception should be viewed as extremely narrow.

Still, Neztsosie is troubling because it reflects the Rehnquist Court's activism in limiting the scope of tribal rights in disregard of fundamental principles of Indian law. By invoking "congressional aims of speed and efficiency" 113 and Congress's "unmistakable preference for a federal forum" ${ }^{\prime 14}$ in passing the Price-Anderson Act, the Neztsosie Court effectively concealed the common law nature of its own judge-made exception to the tribal court exhaustion rule beneath a mantle of seemingly statutory interpretation. Moreover, Neztsosie does not mention, let alone give any weight to, the congressional "policy of supporting tribal selfgovernment and self-determination" 115 underlying the tribal court exhaustion rule in "explaining" why the rule should not apply in this case. Hence, instead of examining the Price-Anderson Act in light of a general, pervasive background policy of congressional respect for tribal sovereignty in accordance with fundamental Indian law principles, the Court declared that the Act's "silence on [removal from] tribal courts" amounted to nothing but "inadvertence," musing further that "[n]ow and then silence is not pregnant." 116

If the Court had been faithful to fundamental principles of Indian law, the Court would have regarded the Act's silence with respect to tribal courts as "pregnant" with congressional intent to respect-or at least not diminish - tribal rights, since congressional abandonment of support for tribal rights requires an express showing of such intent. ${ }^{117}$ Viewed in this way, Neztsosie illustrates the Rehnquist Court's tendency to inject into its common law decision making a judicial policy choice of extinguishing or limiting Indian rights while simultaneously attributing this anti-tribal choice to Congress.

Still, Neztsosie, like Strate, ostensibly reaffirms the tribal court exhaustion requirement, albeit in the context of another decision restricting 
Indian rights. This observation-especially in view of the narrowness of the Neztsosie exception - gives rise to cautious optimism that the Supreme Court will continue to uphold Congress's policy of supporting tribal courts through judicial enforcement of the tribal court exhaustion rule. ${ }^{118}$

\section{Additional Specific Legal Issues Facing Tribal Courts}

Besides contending with new restrictions on inherent tribal adjudicatory authority in Indian country dictated by the Supreme Court and further constraints stemming from the Court's narrow view of the meaning and extent of "Indian country," Indian tribes today face a host of additional complex legal issues in administering justice within reservation communities. The following is a nonexhaustive sampling of these pressing issues. Each issue is described briefly, with an understanding that the law pertaining to most of these issues is still in the early, formative stages of development. Needless to say, tribal courts will be at the forefront of developing these and other cutting-edge legal issues in the future.

Enforcement of judgments. Tribal courts increasingly face issues about whether to enforce foreign judgments in tribal courts. This includes state court judgments and judgments of other tribal courts. ${ }^{119}$ This may occur, if at all, through tribal council legislation, adoption of an applicable tribal court rule, ${ }^{120}$ or tribal judicial recognition of comity. Such decisions are strictly tribal in nature. There is no federal (or state) law that requires tribal courts to recognize foreign judgments. It is clearly a matter of tribal sovereignty.

Civil rights/separation of powers. As tribal government competence continues to grow, there will be (there already is) a concomitant growth in the expectations of tribal citizens as to the level of performance they can expect from tribal officials and tribal institutions. As a result, there is likely to be an increase in litigation involving tribal official and tribal government performance in such areas as civil rights, tribal employment matters, and elections. The ability of tribal courts to resolve these matters fairly and equitably is also a key ingredient in achieving a proper balance of power within tribal government as a whole.

Sovereign immunity. An extraordinarily thorny and increasingly prominent issue facing tribal courts is the extent of the immunity of a sovereign government—-tribal, federal, or state-from tribal judicial process. Like all sovereigns, Indian tribes generally cannot be sued without their consent. Hence, in a suit against a tribe or tribal entity, tribal courts must conduct a careful inquiry into such complex questions as whether the tribe has waived its immunity, the scope of any existing waiver of sovereign immunity, whether a tribe's retained sovereign immunity shields individual tribal officers from judicial process or liabili- 
ty, and whether the tribe's immunity has been abrogated by a federal statute enacted pursuant to Congress's "plenary power" in Indian affairs. Another set of difficult legal questions involves the amenability of states and state officers to civil suits in tribal court for alleged violations of federal or tribal law. These questions concerning the applicability of state sovereign immunity in tribal court are likely to become increasingly important in the wake of several cases decided in recent years by the United States Supreme Court insulating states and state officials from both federal court and state court suits alleging violations of federal law, including federal law protective of Indian rights. ${ }^{121}$

Commercial law. There is no doubt that issues of commercial law will continue to grow in significance within most, if not all, tribal courts within the project region. This is a natural outcome of the varying levels of increased economic development and commercial activity within this portion of Indian country. Much, but not all, of this activity is both directly and indirectly a result of gaming activity within the reservations.

As tribes as well as tribal members, nonmembers, and profitmaking-entities go forward ever more briskly in the business arena, there will be (there already is) an increase in the borrowing of money to serve as venture capital to support commercial endeavors as well as the commerce generated by the business entities themselves that deliver the products and services. All of these endeavors raise the conventional issues related to secured (and unsecured) transactions, foreclosing on loans, the transfer of negotiable instruments, and the role of the Uniform Commercial Code (UCC) within the various tribal codes. All of these issues are potentially complicated within the reservation context because of the trust status of much tribal property, the enforcement and execution of judgments both on and off the reservation, tribal sovereign immunity, and the cultural values at play in matters of commerce.

Many of these issues are more legislative than judicial in nature, but as with any legislation, especially legislation that is both new and complex, litigation is likely if not inevitable. Since the stream of commerce within the reservation reflects elements of the pursuit and exercise of both economic and legal (political) sovereignty, there is no doubt that tribal courts will be a central institution in establishing a legal regime that fosters and enhances local commerce but with a sense of equity and cultural sensitivity.

Although the pressures to adopt wholesale the commercial lawespecially the UCC - of the dominant society are considerable, it is worth recalling —as in the federal/state context—-that there is also considerable legal and normative space for competing sovereigns to approach issues differently but equitably. As elsewhere, there is the not uncommon tension and challenge of clearly desiring economic 
development and commerce but seeking to regulate it within a context of equity and appropriate cultural scale.

Criminal law and alternatives. While tribal courts will continue to handle a large volume of criminal cases, there will be both renewed and new effort, at least in part, to approach these cases through innovative means. These means will include the use of sentencing circles, elder "peacemakers," and alternatives to jail time as ways of pursuing a restorative justice that works to heal the perpetrator, nurture the victim, and enhance the well-being of the entire community.

Administrative law. Administrative law is likely to be the fastest growing area of law on most reservations. As tribes become increasingly active in such areas as alcohol and beverage control, gaming, environmental regulation, telecommunications and utilities, education and elections, they will enact more and more administrative law. Such activity will potentially raise questions of the substantive reach of such legislation, the scope of administrative rule making, the governing agency structure, the scope of agency adjudicatory authority, and judicial review. Tribal courts will be the primary forum for resolving such questions.

Tribal tradition and custom (common law). Tribal courts will continue their efforts to use tribal tradition and customs as key elements of a developing tribal common law used to resolve questions in which there is no positive tribal law on point. The importance of tribal common law is that it provides an important connection to long-held cultural understandings that provide rules and guidance for resolving significant disputes and conflicts on the reservation.

\section{ESTA BLISH M N T OF GREAT SIOUX NATION J U D I C I A L S U P P O R T C E N T ER}

\section{Institutional Prerequisite for Establishing the Great Sioux Nation Supreme Court}

The primary project objective of establishing a Great Sioux Nation Supreme Court is of such significant legal and cultural magnitude that it calls for careful analysis and reflection, particularly in understanding the movement and transition from what is to what (potentially) will be. New institutions, if they are to be successful, need foundations of support and understanding that will nurture and encourage their success. Without a solid foundation, any new situation is likely to totter and fall with the slightest pressure or shift in the wind.

Just as the various state supreme courts and the United States Supreme Court carry out their responsibilities with an adequate staff and reliable infrastructure, so must it be for the Great Sioux Nation Supreme 
Court. The locus and identification of this infrastructure would be in the establishment of the Great Sioux Nation Judicial Support Center. As the name implies, the Center would provide a range of support activities for existing tribal courts; develop several specialized projects related to legislative drafting, constitutional revision and economic development as they pertain to the development of institutions and law on the several reservations; and implement a strong research and administrative base for the Great Sioux Nation Supreme Court itself. This cluster of activities contains the potential for establishing an innovative model and paradigm to link together a series of important judicial and law-related activities within a historically resonant and culturally sensitive context. This has never been done before in Indian country.

\section{Great Sioux Nation Indian Law Library}

A necessary ingredient of many, if not all, of the projects listed above is the availability of an adequate research base. This would require the establishment of a Great Sioux Nation Indian Law Library that would include a complete and thoroughly cataloged collection of the treaties, constitutions, codes, compilations of custom and tradition, and judicial decisions of the participating tribes. In addition, there should be representative examples of all of these classes of documents selected from other tribal efforts around the country.

It goes without saying that such a library is critical to any effort to enhance the quality of judicial decision making and the development of law within the project area. Very few, if any, of the participating tribes currently have anything approaching an adequate law library, and certainly the proposed Great Sioux Nation Supreme Court cannot proceed or succeed without one. Wherever possible these resources should be made available on-line so that participating tribal courts can avail themselves of this information rapidly without actually traveling to the library or using the cumbersome mail system currently in place.

This collection-ideally at least-should be supplemented in several ways. The library needs an adequate "federal" component given the substantial, even dominating, role federal law plays in Indian law even at the tribal court level. This part of the collection would include respective sets of United States Reports (U.S.), Federal Reporter (F., F.2d, F.3d), Federal Supplement (F. Supp.), United States Code Annotated (U.S.C.A.), Code of Federal Regulations (C.F.R.), and United States Code Congressional and Administrative News (U.S.C.C.A.N.). It should also be supplemented by representative codes and constitutions of other tribes across the United States and an ongoing subscription to the Indian Law Reporter. Finally, it should be supplemented-where possible - with tribal histories and other archival materials related to 
oral tradition and custom. The latter might be developed in conjunction with the efforts already undertaken by the tribal colleges on many of the reservations.

\section{Great Sioux Nation Indian Law Research Component}

Inevitably, the much discussed research needs to be done by someone. As described elsewhere, the project does not (or ought not) envision the relevant research to be performed by tribal judges themselves. It is in this vein that the project proposes the establishment of a Great Sioux Nation judicial research fellow to perform much of this work.

The Great Sioux Nation judicial research fellow (or fellows, as the case may be) ideally would perform a number of functions. The primary fellow would do research as directed by the chief justice to develop appropriate memoranda pertinent to cases before the Court. In addition —on a directed basis— the fellow could engage in research for participating tribal courts at the trial and/or (if preserved) intermediate appellate level. This research undoubtedly would facilitate a reduction in the time that it would take to decide cases as well as an improvement in the quality of those decisions. Timely and thorough research is a critical variable in the administration of justice within any judicial system and certainly cannot be overlooked in the context of the Great Sioux Nation Supreme Court.

In addition to spending some time at the University of South Dakota School of Law doing this significant research, the fellow also would teach a one-credit special topics class within the field of advanced Indian law at the law school. This would present law students at the University of South Dakota with a unique opportunity for advanced, specialized learning within the field of Indian law. In turn, the (at least part-time) presence of the fellow at the law school would greatly enhance the stature of the institution. In addition, the availability of the teaching component for the fellow would likely broaden the pool of applicants for the fellow position because it would contain both research and teaching elements that are so attractive to the best and the brightest of recent law school graduates.

In addition to these primary research and teaching activities, the judicial research fellow could be detailed to perform other research and administrative tasks. The necessity for other kinds of research and writing is elaborated below. ${ }^{122}$ More than likely, however, will be the need for an additional fellow (or two!) to undertake and sustain these complementary projects. The fellow(s) could also have as a responsibility the duty to establish research and intern opportunities for law students both during the academic year and during the summer. This would greatly increase the capacity of the Center and provide unique and exceptional opportunities for students. This is especially signifi- 
cant with the increasing number of Indian and other interested students at the University of South Dakota and the University of North Dakota law schools.

\section{Great Sioux Nation Law and Culture Journal}

A natural outgrowth of the various projects might be a strictly scholarly endeavor tentatively identified as the Great Sioux Nation Law and Culture Journal. This journal might be coordinated through the University of South Dakota School of Law and a tribal college, such as Sinte Gleska University, and would serve to highlight the legal and cultural issues that develop within the project area as they are reflected in the Court and/or within the tribal communities themselves.

Such a journal would also provide a potential medium for exploring issues identified within other components of the Reconciliation Project, including repatriation, commerce, and community mediation. All of this in its broadest form might engender important scholarly and community dialogue about reconciliation and the cultural, political, and economic interactions among Indians and non-Indians, including the respective governmental institutions.

In any event, such a journal may be the ideal vehicle for extending the efforts of the diverse project undertakings to a larger statewide and even national community of individuals interested both personally and professionally in these issues. In its own curious way, the journal might represent a bicultural approach to the theme of "contact" and interaction as initially witnessed in the journals of Lewis and Clark. The journal might serve as an adjunct or catalyst in the ongoing-often painful-process of contemporary "contact" and interaction.

\section{Great Sioux Nation Legislative Drafting Project}

This project—while not judicial in nature-possesses great merit and has much good to offer. Tribes today, including the tribes within the project area, are (for better or worse) enacting more law than ever before in the modern era. This trend is not likely to abate. As the federal government and various state governments continue to pass more and more laws to keep up with the demands of an ever more complex society, a parallel proliferation of lawmaking is occurring at the tribal level. Much litigation that follows the enactment of these myriad laws is diwrangling and litigation.

The importance of good legislative drafting is severalfold. As 
noted, it can help to avoid costly, time-consuming, and fractious litigation, but on the more positive side, it can encourage harmony, political integrity, and respect for law as a valuable social and cultural embodiment of significant tribal values. In addition, while there is no doubt that the amount of law on the reservation is increasing, it is also true that much of the new tribal legislation-from water codes to the Uniform Commercial Code to cultural preservation and repatriation-is increasingly complex. This factor of growing complexity also ratchets up the demand for improved and more thoughtful legislative drafting.

Such efforts as the Legislative Drafting Project are innovative in that they seek to establish a more holistic approach to the making and development of law than is attainable with a narrow judicial focus. This is one instance where an undue formalistic emphasis on the separation of legislative, executive, and judicial functions can do more harm than good. None of this, of course, is meant to suggest an obliteration of the time-honored distinctions embedded in the concept of separation of powers, but only to suggest that the greatest effectiveness and renown will attend to the project that can blend the old and the new to usher in the best of all possible worlds.

The Legislative Drafting Project has at least two other benefits. First, given the makeup of the tribes within the project area, there is great likelihood that two or more tribes will be considering identical substantive problems at the same time, and hence a greater efficiency and potential unity will result. Second, concern for the absence of appropriate financial resources within many tribes to employ counsel to research and draft desired legislation permits this particular project to provide a most needed service at little or no cost to the participant tribes.

In some cases, there may even be the opportunity to draft model legislation on diverse topics ranging from cultural preservation and repatriation to the execution of judgments that would help meet the needs of more than one reservation within the project region and even nationally. Most certainly, no such project currently exists anywhere in the country, and the time is indeed ripe for such an innovative effort. This is one of potential projects that not only meets a well-recognized need but pushes beyond it and takes things to another level.

\section{Great Sioux Nation Constitution Revision Project}

One of the major tribal legal developments of the past decade or so has been the serious commitment of many tribes to revisit their tribal constitutions with an eye to considering their adequacy for the present and future and, more specifically, to envisioning what kinds of amendments are necessary or appropriate. This movement is significant in both obvious and perhaps not so obvious ways. Any time a sovereign considers amending or altering its constitution it signals a political/ 
cultural perception about the need for change. This is both exciting and risky business.

In addition, in the context of Indian law, this recent movement for constitutional reform indicates a growing concern by tribes about both the legitimacy and substantive soundness of pivotal governing documents, which in many cases were adopted pursuant to the often heavy-handed influence of the Bureau of Indian Affairs exercised pursuant to section 17 of the 1934 Indian Reorganization Act. ${ }^{123}$ Many IRA, and even non-IRA, constitutions are essentially boilerplate versions designed by the BIA without any real participation by the tribes themselves. Therefore they often lack the true stamp of tribal ownership and legitimacy. Coupled with these problematic origins, there are often questions relating to substance in such critical areas as territory, jurisdiction, membership, powers of the legislative and executive branches, status of the tribal judiciary, balance of power (separation of powers), and relationship to the federal government.

This Constitution Revision Project is one that holds much potential. For example, such a framework would encourage the collection of tribal constitutions of all types_-both IRA and non-IRA—especially constitutions adopted in recent years, as well as relevant tribal cultural and constitutional histories. With such a collection in place, a workshop might be conducted to review the options and choices tribes have made both historically and in recent times.

In addition, the project could also develop a short pamphlet that discusses constitutional adoption, revision, and amendment procedures that reflect both IRA and tribal (i.e., non-IRA) approaches to this question. Besides a description of the technical steps, such a document could address the importance of participation by tribal people in this process itself through informed discussion at the community level up to and including the calling of a tribal constitutional convention.

Lastly, there should be the opportunity to consider tribal constitutions not only in terms of structure, substance, and procedure but also in the framework of values and aspirations. What are the values and aspirations that tribes want to see embedded and identified in their constitutions? Unfortunately, too much discussion of tribal constitutional revision focuses on technical matters of structure and procedure (which of course are important) and not on the values constitutions seek to realize and the aspirations they seek to vindicate. There is not only the constitutional text but also its supertext that makes clear its connection to tribal values and culture. Finally, the project would be available to assist in the more obvious task of drafting relevant amendments or entire constitutions for interested tribes, and perhaps even to prepare a "model" tribal constitution—not as any prepackaged answer but as a vehicle to generate and support tribal constitutional discussion.

Of course, it goes without saying that any of the workshop's 
potential activities could be performed on-site on any reservation within the project area. Constitutional discussion and revision is likely to be one of the primary vehicles for tribal "reform" in this new century. Therefore it seems timely for the supportive involvement of the Great Sioux Nation Judicial Support Center in these efforts. This is yet another example of an opportunity for the project to be not merely helpful in a judicial sense but to be truly innovative in working with tribes not only at the center but at the cutting edge of the use and syntax of law.

\section{Great Sioux Nation Law and Economic Development Project}

Outside the strict confines of law, but nevertheless deeply embedded in it, is the struggle and commitment of tribes to advance economic development within their reservations. Economic development, despite being often discussed in blind imitative reference to the majoritarian society, is a frontline issue for most tribes as they seek to address the extensive poverty that exists throughout Indian country, but particularly in the project area. With four of the poorest counties in the United States located in this part of Indian country, the need for economic development is painfully obvious.

Whether poverty and unemployment are analyzed through the more conventional lens of attracting outside business and capital to the reservation or from the vantage point of an indigenous approach of encouraging local efforts that are modest but culturally consonant, questions of tribal policy and law inevitably need to be addressed. These questions include such things as the role of the tribe as an active participant and player in economic activity; the nature of the law governing corporate, partnership, and limited partnership efforts within a reservation; the role (if any) of sovereign immunity; Indian preference in hiring and promotion, taxation, jurisdiction; and the match of tribal law to the primary rules of commerce outside the reservation, such as the Uniform Commercial Code.

These questions are not academic or futuristic but pragmatic and real. The incredible jumpstart (however modest the results to date) of Indian gaming has brought many of these issues to the forefront of tribal governmental and judicial concern. In fact, it is likely true in some cases that the speed of potential economic change itself has presented new opportunities and challenges to tribes that only a short time ago would have been inconceivable. For example, it is difficult to envision the partnership of Bell Farms, Inc., and the Rosebud Sioux Tribe to create the largest hog farm in the western hemisphere without the experience of Indian gaming as a precedent for large capital investments for joint ventures of considerable economic complexity. This large-scale example is provided neither to applaud nor to criticize, but merely to 
illustrate the rapidly changing and evolving terrain of tribal economic development.

Much of this kind of development involves not only the type of legal issues described above, but also questions of values, culture, and economic theory. It is in the interweave of these questions with policy and law that such a Law and Economic Development Project could be particularly useful in parsing the competing demands and the myriad options that go with it. In this area, tribes may seek assistance that goes beyond the strictly legal and delves into the realm of economic analysis, infrastructure capability, and environmental impact. Many tribes currently lack the resources to make these assessments on their own, and the Law and Economic Development Project would be an invaluable asset in this regard.

In addition, the Law and Economic Development Project would be a valuable force to produce informative case studies of economic development efforts in Indian country in order to try to identify the most likely mix of leadership, law, and culture that maximizes economic advancement. In the economic development arena, the question of how one replicates success (one's own or someone else's) is a core concern that could be profitably explicated within the mission of such an effort.

Tribal economic sovereignty and self-determination are obvious complements to tribal political sovereignty and self-determination. In fact, it might be argued that without companion economic development, meaningful self-determination cannot grow because economic constraints and lack of resources make it nearly impossible to realize these legal and cultural benefits. With this in mind, the Law and Economic Development Project makes eminently good sense with its realization that advancements in tribal government are more likely to occur, flourish, and become long-lasting when they rest on a secure economic base. This is another example where the potential of the Reconciliation Project_- particularly the Great Sioux Nation Judicial Support Centerto be innovative and truly responsive to the needs of the tribes within the project area is quite real. It is further likely that the participating tribes will manifest a deeper sense of commitment and ownership of the Judicial Support Center because of its very willingness to push beyond the merely pedestrian to something that strikes a spark for genuine change and dialectical encounter.

Without the establishment of a Great Sioux Nation Judicial Support Center to provide assistance to existing tribal courts while establishing infrastructure support for the Great Sioux Nation Supreme Court itself and creating some innovative related projects, it is quite unlikely that the Great Sioux Nation Supreme Court will truly take root and blossom. The proposed Center advances the likelihood of meaningful success and reduces the likelihood of outright failure or mediocrity. 
The idea for a Great Sioux Nation Supreme Court is an exciting and long-held cultural ideal and vision of the tribes of the Great Sioux Nation that is fully embraced and promoted by the Reconciliation Project. It is a concept that has been around since the beginning within this part of Indian country as a potential capstone effort that would establish a kind of (renewed) cultural and legal continuity within the historical Great Sioux Nation as recognized, for example, in the Fort Laramie Treaties of 1851 and 1868 . This point-which on some level is quite obvious - needs to be reiterated in order to avoid potential problems about the roots and lineage of this legal milestone. Nothing can dissipate support for a project more quickly than wrangling about whose idea it really is.

In this vein it is probably best to understand the project as facilitating the realization of a long-held historical and cultural ideal in accordance with tribal participation and leadership to cooperatively operationalize this long-held tribal vision. With this in mind, what follows is a preliminary effort to identify and discuss the relevant questions in order to facilitate implementation of the Great Sioux Nation Supreme Court. These issues are the quintessential core questions that need to be answered in order to establish an adequate legal foundation from which to operationalize this historical endeavor. The ensuing discussion is meant simply to raise the issues, to suggest the options and range of choices, and then at some later time (as directed) to flesh out comprehensive, particularized details and suggested courses of action.

\section{Composition (Participating Tribes)}

The very first consideration is identifying who are the eligible tribes to participate in the Great Sioux Nation Supreme Court. This is a not insignificant question, but one on which rests a baseline legitimacy. A Court calling itself the Great Sioux Nation Supreme Court (or Sioux Nation Supreme Court) must indeed represent the Great Sioux Nation. At this time there are at least three possibilities:

1. All the Sioux tribes within the current project area of South Dakota, North Dakota, and Nebraska. This would include eleven tribes: nine tribes in South Dakota and one each in North Dakota and Nebraska. They are:

a. South Dakota: Rosebud, Oglala (Pine Ridge), Cheyenne River, Standing Rock, Lower Brule, Crow Creek, Yankton, Flandreau, and Sisseton (Lake Traverse) 
b. North Dakota: Spirit Lake

c. Nebraska: Santee

2. The tribes that are signatories of the Fort Laramie Treaties of 1851 and 1868 . These tribes are often referred to as the Great Sioux Nation within the treaties and related litigation. They are eight in number and include Rosebud, Oglala (Pine Ridge), Cheyenne River, Standing Rock, Lower Brule, Crow Creek, Santee Sioux of Nebraska, and Fort Peck Sioux in Montana.

3. All tribes that are recognized as Sioux. This would include all the tribes in numbers 1 and 2 and the following tribes in Minnesota: Lower Sioux Reservation (Morton, Minnesota), Upper Sioux Reservation (Granite Falls, Minnesota) Prairie Island Settlement (near Red Wing, Minnesota), and Prior Lake Reservation (near Mankato, Minnesota).

In addition, several tribal bands in Canada are recognized as Sioux. These include the Bird Tail, Sioux Valley, and Sioux Village in Manitoba $;$ and the Standing Buffalo, Moose Woods, Round Plain, and Wood Mountain in Saskatchewan.

This question concerning the composition of the Great Sioux Nation Supreme Court raises the foundational question about $w$ bo determines which tribes are invited to participate in the formation of the Great Sioux Nation Supreme Court. If the Historical Society is to do this, it is unlikely to have the necessary historical and cultural expertise. Perhaps a certain core group of Sioux tribes such as the Sioux tribes in South Dakota or the signatories to the Fort Laramie Treaty of 1868 might be asked to take on this responsibility. It is definitely a threshold question that must be answered and will likely set the tone for the entire project.

\section{Relationship to Existing Tribal Appellate Courts}

The next logical structural and organizational question is: What is to be the relationship of the Great Sioux Nation Supreme Court to existing tribal appellate courts? One view appears to be that the newly formed Court should simply replace all existing tribal appellate structures with one superstructure. This is problematic for several reasons. Such an approach would create a veritable tidal wave of appeals_-of all kinds-for the new Court to consider. This wave might well swamp the Court before it ever got started. Also, it would not really be a qualitative move forward but more of a new replacement for those already existing tribal courts of appeals. While there is some argument to be made in this vein as establishing a broader band of legal uniformity 
across the legal horizon of the participating tribes, this very same effort can be accomplished by a Great Sioux Nation Supreme Court that does not replace existing tribal courts of appeals and at the same time preserves a significant amount of legal space for tribal diversity within noncontroversial areas of the law.

The structural question is also closely related to the issue of the Great Sioux Nation Supreme Court's jurisdiction, which is discussed below. ${ }^{124}$ The essential point of a Great Sioux Nation Supreme Court is not necessarily to decide routine cases of local import, but rather to decide cases that have significant import across the Sioux Nation as a whole. Here an analogy to the United States Supreme Court is instructive. The United States Supreme Court hears only those cases that have national import and/or that involve conflicts between different circuit courts of appeals or between a circuit court of appeals and a state supreme court. It does not exist to ultimately resolve questions of local application if there are no broad implications or conflicts with other local forums. It is properly understood as an institution of history instrumental in reflecting and articulating the accomplishments and aspirations of law.

For all of these reasons, it is clear-despite the reality of a more complex structural and procedural system-that the Great Sioux Nation Supreme Court should not simply replace existing tribal appellate courts. This would likely be a step backward rather than forward. The challenge is not to avoid the attendant complexity but to master and transcend it in order to achieve a new level of jurisprudence and historical/cultural continuity.

\section{Qualifications and Selection of Justices}

Both the qualifications of justices for the Great Sioux Nation Supreme Court and the method of selecting them present a significant range of possibilities. Most tribal appellate courts in the project region require that a majority, if not all, of appellate judges be formally law-trained and admitted to practice law in some state or federal jurisdiction. In addition, some appellate courts require a certain amount of experience. Some appellate courts require that at least one member of the court speak the (tribal) language and be knowledgeable about tribal tradition and culture. Usually such a member of the court does not have to be law-trained. Almost all tribal appellate systems in the region have three-member courts. The Rosebud Sioux Supreme Court has six members, but sits in three-judge panels with an en banc capacity. The Northern Plains Intertribal Court of Appeals sits in panels with one judge from each participating tribe. Almost all tribes follow officially or unofficially Indian or tribal preference in the selection of judges. This range of possibilities reveals a clear trend toward requiring that 
tribal judges be law-trained and admitted to practice, with some concern about explicitly guaranteeing some representation by individuals who know the language and culture. Resolution of this critical issue clearly requires more study and tribal consultation.

Depending on the number of participating tribes-which potentially runs as high as eleven or twelve-there may be some concern that a Court of so many justices is unwieldy. It is true, however, that many international courts have as many or even more sitting justices. At this stage, the potential problem is simply identified.

The actual selection of the justices by the participating tribes involves several possibilities. One is simply to leave it to the respective tribes' discretion. The other is to mandate a uniform process such as selection/appointment by the tribal council or selection as part of a tribewide election. The latter process is obviously more time-consuming and raises questions about how one gets on the ballot, eligibility to vote, costs, etc. Obviously, the uniform federal practice is by appointment, while the state practice is often a mixture of initial appointment and subsequent reelection. Tribal approaches include both appointment and election. The use of an election procedure involving so many separate tribes appears quite cumbersome, but perhaps that is insufficient to rule it out.

Another obvious issue is the duration of office. Likely term possibilities are four, six, or eight years. Two-year or even three-year terms appear too short to allow the Court to establish roots, consistency, and the necessary rules that face any court in its initial steps of development. On the other end, lifetime appointments are possible, but are not currently used by any tribe within the Sioux Nation. Yet perhaps the importance and historical significance of the Great Sioux Nation Supreme Court suggest the necessity of a stronger consideration of this possibility.

Other concerns in this area include adopting a process to stagger the terms of the justices (obviated if subject to lifetime appointments) to avoid continuity problems, selection of a chief justice (presumably elected by fellow justices) and her or his term of office. And finally there is need for provisions (substantively and procedurally) for impeachment and removal from office and the selection of judicial successors. Details about these options and procedures can be spelled out in further detail once the project and the participating tribes winnow down the range of choices to perhaps one or two possibilities. It does not make a good deal of sense to get out a comprehensive blueprint at this point.

\section{Enabling Legislation and Judicial Rules}

The transforming legal event in establishing the Great Sioux Nation Supreme Court will be the adoption of (uniform) enabling legislation 
by the participating tribes. Adoption of this enabling legislation will officially establish the Great Sioux Nation Supreme Court and inaugurate the process for the selection of judges and, ultimately, the process for hearing and deciding cases. Such legislation-as this part of the report indicates-must identify the rules and principles to govern in at least six areas of concern, namely, composition of the Court, qualifications and selection of justices, relationship to existing tribal appellate systems, jurisdiction, governing law, and enforcement of judgments.

While such enabling legislation cannot be expected to answer every structural and/or procedural question, it must answer enough questions so that the Court can become operational. At the same time, it is probably fruitless to leave all of this up to the Court itself without sufficient legal guidance or direction. In this vein, it is therefore necessary to explicitly identify and recognize the ability of the Court to adopt judicial rules to meet situations not identified by the enabling legislation. These rules would be largely procedural in nature and would mainly serve as gap fillers. All tribal courts in the project area currently possess some form of judicial rule-making authority. This is particularly necessary in the context of establishing appellate rules of procedure governing such items as timelines, length of briefs, the granting of oral argument, etc.

In a related context, it is necessary that the Court be given the appropriate authority to regulate the admission to practice before the Great Sioux Nation Supreme Court. Again, the most common approach of the tribal courts in the project area includes requiring that practitioners be admitted to practice in federal court and/or the highest court of a state. A few tribes-notably the Rosebud Sioux Triberequire that a candidate for admission successfully pass a tribal law examination. In addition, most tribes permit "tribal advocates" or "lay advocates" — usually identified as individuals who are tribal members and who possess minimal education requirements (usually a high school diploma)— to practice before tribal courts. It is a legitimate issue whether this classification of practitioners should be eligible to practice before the Great Sioux Nation Supreme Court. This is particularly true in the appellate context where the ability to write a brief is absolutely essential.

In addition, there are the complementary issues of regulating the ability of litigants to proceed pro se and enabling the Court to appoint pro bono counsel to represent indigent pro se litigants. This latter issues raises important questions about ensuring quality representation for litigants in the context of such a historical undertaking. Therefore some additional discussion is needed in this context.

It makes sense-and necessarily follows-that on the practice side what naturally flows from the issue of admission to practice before the Great Sioux Nation Supreme Court is the importance and viability 
of establishing a Great Sioux Nation Supreme Court Bar Association. The importance of such a bar association is not only that it will encourage face-to-face esprit among practitioners about their commitment to the quality and success of the Court but, in addition, it can perform a range of services, from processing applications for admission to practice and providing continuing legal education (CLE) opportunities, to developing membership lists for pro bono appointments, to handling most disciplinary matters. The successful discharge of these functions will greatly advance the likelihood that the Great Sioux Nation Supreme Court will establish a wide swath of legitimacy and a broad range of competence. Historically, bar associations have been critical partners of the judicial infrastructure in the effort to advance judicial legitimacy and also to provide a set of significant services that otherwise would overburden courts or go undone altogether.

With these advantages in mind, it is definitely advisable that the establishment of a Great Sioux Nation Supreme Court Bar Association go hand-in-hand with the creation of a Great Sioux Nation Supreme Court. This, of course, is likely to involve developing a separate set of administrative rules identifying the conditions of membership, procedures for electing officers, and the range and scope of activities, whether mandatory or discretionary, encompassed within the bar association's statement of purpose. Without such a bar association, the ability of the Court to obtain legitimacy and to flourish will be severely constrained.

In sum, the enabling legislation adopted by the participating tribes must set out the broad principles governing the structure of the Court in such matters as the qualifications and selection of justices, requirements for admission to practice, establishment of a bar association, and explicit authorization for adopting judicial rules needed for regulating local practice and advancing the administration of justice. In addition, there are the weighty substantive concerns relative to jurisdiction, governing law, and enforcement of judgment. These discussions follow.

\section{Jurisdiction}

Perhaps the penultimate question for any court-especially a tribal or intertribal court enmeshed in the uncertainties of much of contemporary Indian law-concerns what kinds of cases (appeals) the court has jurisdiction to hear and whether such jurisdiction is discretionary or mandatory in nature. Therefore two questions arise, each to be discussed in turn: (1) How shall the Great Sioux Nation Supreme Court exercise its jurisdiction? and (2) What is the nature or scope of the Court's jurisdiction?

Exercise of jurisdiction. This inquiry — at least at this stage-may 
be broadly conceived as whether the Court's jurisdiction is mandatory or discretionary or some combination thereof $f_{i}$ or, to put it from the perspective of the litigants, whether a party may appeal as a matter of right (in which case the Court must hear the appeal), or only as a matter of discretion (or, in United States Supreme Court parlance, through a petition for a writ of certiorari), or some combination thereof. It seems highly unlikely that either extreme-all cases being appealable as a matter of right or no cases being appealable as a matter of right—would be appropriate. The former (especially with preservation of current tribal appellate courts as intermediate courts of appeals) would likely overburden the Court with too many rather routine or mundane appeals. The latter would allow the Court to avoid cases (although such avoidance would be unlikely) considered too controversial or politically volatile and might appear to give the Court too much power to set its own docket.

The test is how to strike a balance or middle ground. This middle ground might identify a range of cases appealable as a matter of right with all others appealable on a discretionary or writ of certiorari basis. While it is clearly difficult to array the possibilities, perhaps an initial grouping suggests that cases involving challenges to tribal jurisdiction, civil rights (e.g., due process/equal protection claims), election disputes, and commercial issues would be characterized as appealable of right, with all other cases deemed matters of discretion. This apportionment is provided as a mere example of a baseline for further discussion.

Scope of jurisdiction. This inquiry clearly overlaps the first, but is more directly involved with what is appealable (whether mandatory or discretionary) in the first instance or otherwise within the Court's purview. This concern raises questions such as the existence or scope of interlocutory appeals, whether the Court will have any original jurisdiction to issue extraordinary writs, and whether the Court will have a certification procedure to respond to inquiries about questions of law from federal, state, or other tribal judiciaries.

Existing tribal appellate courts run the gamut on these matters. Some say yes; some say no; while others are silent in whole or in part. Most state courts and the federal courts recognize some kind of interlocutory appeals procedure and usually do possess some limited form of original jurisdiction. A few have provisions for certification.

Obviously these issues need to be explored in more detail. Yet it goes without saying that a central tenet of legitimacy and stability is consensus and common understanding about the scope of an appellate tribunal's substantive jurisdiction and the procedural devices available to invoke that jurisdiction. Potential confusion or inconsistency in this realm clearly threatens stability and therefore a most careful consideration of these jurisdictional issues is crucial. 


\section{Governing Law}

The issue of what is to be the appropriate governing law presents some provocative and sticky questions. While ordinarily a tribal court (or even an intertribal court) simply applies the appropriate federal and/or tribal law to resolve the dispute, the Great Sioux Nation Supreme Court, as a court made up of related but autonomous tribal nations, faces the issue of whether to simply apply the law of the tribe from which the appeal comes or whether the Court may use federal or tribal law principles that differ from the local law of the tribe in order to fashion a more encompassing or appropriate result. This is further complicated by the fact that in a given case or related cases from two different participating tribes an identical legal question may suggest two different results because, for the example, the tribes have different ordinances or constitutional provisions.

This issue suggests a broad jurisprudential concern. Is it to be an objective of the Court to articulate, wherever possible, broad synthesizing principles and interpretations that establish rules and precedents that are binding across the Great Sioux Nation, or else to merely decide cases in accordance with the local law of the particular tribe without concern for broader implications or possible conflicts with the law of another constituent tribe? This is not unlike the broad issue of contemporary federalism in discerning those parameters of federal and state authority between the poles of uniformity and variance. Yet there is a cardinal difference in the analogy because the United States Constitution provides the broad template for deciding federal-state zones of authority. There is, of course, no Great Sioux Nation Constitution to set the broad parameters.

Perhaps there is a middle ground to provide a baseline for this discussion as well. The middle ground might be that cases that are decided on rules of federal law-whether constitutional, statutory, or Supreme Court precedent-would be binding across the Sioux Nation, while cases decided on local tribal law-whether constitutional, statutory, customary and traditional, or common law-would be binding only on the affected tribe. Of course, even these categories may overlap and intersect, but they certainly do provide a basis for making some initial, workable distinctions.

In turn, this discussion raises an overarching policy and values question about the Great Sioux Nation's conception of its Supreme Court: Is the objective uniformity, diversity, or a principled blend of both? Again, there is no right or wrong way, but there is a need for a consensus view in order to avoid a breach of commitment to the $\mathrm{Su}$ preme Court stemming from a misconception or misunderstanding of the Court's purpose. No final decision is possible without additional discussion of this matter. 


\section{Enforcement of Judgments}

It goes without saying that any judgment of the Court is enforceable by its terms within the territory of the participating tribes. Any judgment of the Court is the "supreme law" of the Great Sioux Nation, not subject to a countermand failure to enforce by any participating tribe. Failure by anyone within the nation to honor the judgments of the Great Sioux Nation Supreme Court will only precipitate a crisis of legitimacy and potentially cause the jurisprudential walls to come crumbling down.

There are other less clear variations on the theme of enforcement of judgments that will need to be addressed. These include, for example, (1) whether judgments of the individual participating tribal courts are to be automatically entitled to full faith and credit in the courts of other participating tribes or whether this is to be decided on a tribe-by-tribe basis; and (2) whether there should be a uniform rule of full faith and credit or comity or complete deference to each participating tribe's policy for the enforcement of state judgments or judgments of nonparticipating tribal courts. Of course, there is the routine procedural question about whether actions for the enforcement of judgments may be brought as an original action in the Great Sioux Nation Supreme Court (presumably not). These issues clearly raise significant policy questions that need to be explored in greater detail by the participating tribes.

\section{CONCLUSION: BOTH PLANAND DREAM}

Inevitably, establishment of the Great Sioux Nation Supreme Courta cultural dream of long-standing-raises issues of values and practicality, aspiration, and operationalization, and all the potentialities in between. This report strives to provide sufficient background discussion of relevant Indian law issues, discussion of the desired infrastructure of a Great Sioux Nation Judicial Support Center, and elucidation of the particular issues that need additional discussion and resolution before the Court can begin its historical mission with confidence and legitimacy. The authors are prepared for-indeed anticipate-the opportunity to discuss the report with all interested parties in order to facilitate identification, understanding, and support for the next phase in this unique and groundbreaking process.

\section{$\begin{array}{lllll}\mathbf{N} & \mathbf{O} & \mathbf{T} & \mathbf{E} & \mathbf{S}\end{array}$}

This report is the product of an endeavor of the University of South Dakota School of Law under a research grant from the Wakpa Sica Historical Society of Fort Pierre, South Dakota. Since drafting the report, the authors have helped the Historical Society conduct a series of tribal roundtable discussions 
in South Dakota and North Dakota for the purpose of refining and elaborating the Reconciliation Place Project to integrate tribal people's observations and concerns. The authors expect to issue a supplemental report reflecting this input in the future.

The authors would like to acknowledge and thank Dean Barry R. Vickrey of USD School of Law for advice and support in completing the report; USD law student Sharon Red Deer, J.D. 2002, for research assistance; and USD School of Law Senior Secretary Mary Ann Hart for data processing and technical support.

1 For an important previous effort at addressing some of these issues, see Draft Articles of the Sioux Nation Supreme Court prepared by Steven C. Emery, Steven J. Gunn, and Thomas J. Van Norman for the Dakota Territory Chairmen's Council, October 24, 1997 (on file with authors).

2 See, e.g., Frank Pommersheim, Braid of Feathers (1995), Judith Royster, Stature and Scrutiny: PostExbaustion Review of Tribal Court Decisions, 46 Kan. L. Rev. 251 (1998).

3 Frank Pommersheim, John LaVelle, and B. J. Jones. All of these individuals are well-known scholars, teachers, and practitioners in the field of Indian law. The tribe-bytribe needs assessment/survey was prepared for the Wakpa Sica Historical Society by B. J. Jones of the University of North Dakota School of Law and submitted separately (draft on file with authors).

4 "Establishment of Great Sioux Nation Judicial Support Center."

5 See, e.g., the services described in the section "Establishment of Great Sioux Nation Judicial Support Center."

6 See the section "Establishment of Great Sioux Nation Judicial Support Center."
7 See, e.g., the needs assessment/ survey prepared by B. J. Jones of the University of North Dakota School of Law (on file with the Wakpa Sica Historical Society).

8 See, e.g., extended discussion in the section "Legal Issues Facing Tribal Courts."

9 See 25 U.S.C. § 1302(6).

10 Currently, within the project area, only the Rosebud Sioux Tribe has a functioning bar association that administers a tribal bar examination and provides limited CLE opportunities.

11 See Special Message to the Congress on Indian Affairs, [1970] Pub. Papers 564 (Richard M. Nixon).

12 Frank Pommersheim, Tribal Court Jurisprudence: A Snapshot from the Field, 21 Vt. L. Rev. 7, 7 (1996).

13 See, e.g., Indian Tribal Justice Act, 25 U.S.C. $\S \S 3601,3602,3611$ to $3614,3621,3631$.

14 John P. LaVelle, Sanctioning a Tyranny: The Diminishment of Ex parte Young, Expansion of Hans Immunity, and Denial of Indian Rights in Coeur d'Alene Tribe, 31 Ariz. St. L. J. 787, 789 (1999).

15 See Felix S. Coben's Handbook of Federal Indian Law 232 (Rennard Strickland et al., eds., 1982) [hereinafter Coben's Handbook] (discussing the independent origin of tribal sovereignty).

1621 U.S. (8 Wheat.) 543, 604-05 (1823) (non-Indian plaintiffs who purported to obtain ownership of land by grant from Indian tribes did "not exhibit a title which can be sustained in the Courts of the United States").

17 See id. at 573-605 (discussing application of the "discovery" doctrine to the question of Indian title). 
1830 U.S. (5 Pet.) 1, 20 (1831)

(holding that "an Indian tribe or nation within the United States is not a foreign state in the sense of the constitution").

19 Id. at 17

20 See 31 U.S. (6 Pet.) 515, 542, 557, 559-63 (1832).

21 Id. at 561

22 See, e.g., id. at 559-60 ("We have applied [the words 'treaty' and 'nation'] to Indians, as we have applied them to the other nations of the earth. They are applied to all in the same sense." ); Cherokee Nation, 30 U.S. (5 Pet.) at 16 ("The acts of our government plainly recognize the Cherokee nation as a state, and the courts are bound by those acts.").

23 See, e.g., Cherokee Nation, 30 U.S. (5 Pet.) at 17-18 (denying Indian tribes the status of "foreign states" by observing that "any attempt [by foreign nations] to acquire their lands, or to form a political connexion with them, would be considered by all as an invasion of our territory, and an act of hostility"). Although the earlier case of Jobnson v. M'Intosb purported to ground its denial of the power of Indian tribes to alienate tribal property in the European doctrine of "discovery," see 21 U.S. (8 Wheat.) 543, 574 (1823), Cherokee Nation's subsequent clarification of Jobnson's holding indicates that the real justification for denying tribes the power to alienate their lands was the Court's concern about the implications of such power for undermining the territorial security of the United States. The Marshall Court's progression from a potentially limitless "discovery"-type rationale to a very restrictive "national security"-type rationale for finding a limitation on the scope of inherent tribal sovereignty is reflected in the Court's recurring doubts about the legal and moral validity of the European "discovery" doctrine, which the Court ultimately found applicable to Indian law disputes only when "glanc[ing] at [the] origins" of colonization and not when "proceed[ing] . . to to the actual state of things," Worcester, 31 U.S. (6 Pet.) at 543. See, e.g., id. (disparaging the "proposition" of "discovery" as "difficult to comprehend"); Johnson, 21 U.S. (8 Wheat.) at 591 (denigrating the "discovery" theory as an "extravagant ... pretension" that "may be opposed to natural right, and to the usages of civilized nations").

24 See, e.g., Worcester, 31 U.S. (6 Pet.) at 556-57 ("From the commencement of our government, congress has passed acts to regulate trade and intercourse with the Indians; which treat them as nations, respect their rights, and manifest a firm purpose to afford that protection which treaties stipulate."); Cherokee Nation, 30 U.S. (5 Pet.) at 17 ("[Indian tribes] acknowledge themselves in their treaties to be under the protection of the United States.... They look to our government for protection.").

25 See, e.g., Worcester, 31 U.S. (6 Pet.) at 560 (adverting to "the universal conviction that... [Indian nations'] territory was separated from that of any state within whose chartered limits they might reside, by a boundary line, established by treaties: that, within their boundary, they possessed rights with which no state could interfere").

26118 U.S. $375,383-84$ (1886) (upholding congressional power to enact the Major Crimes Act of 1885).

27 Id. at 384 .

28 See id. at 378-79 (declining to identify the Indian Commerce Clause as the source of congressional power to enact the Major Crimes Act) ${ }_{i}$ id. at 384-85 (de- 
claring that power over Indians "must exist in [the federal] government, because it never has existed anywhere else, because the theatre of its exercise is within the geographical limits of the United States, because it has never been denied, and because it alone can enforce its law on all the tribes").

29 See id. at 379 (stating that Cherokee Nation "held that the Cherokees were not a State or nation within the meaning of the Constitution"); id. at 382 (stating that in Cherokee Nation, "it was held that these tribes were neither States nor nations"). But see Cherokee Nation, 30 U.S. (5 Pet.) at 16 ("The acts of our government plainly recognize the Cherokee nation as a state, and the courts are bound by those acts."). See also Kagama, 118 U.S. at 381-82 (stating that Indian tribes have a status under federal law "not as nations, ... but as a separate people"); id. at 379 ("The soil and the people within [the geographical] limits [of the United States] are under the political control of the Government of the United States, or of the States of the Union. There exist within the broad domain of sovereignty but these two."). But see Worcester, 31 U.S. (6 Pet.) at 555 (observing that under a treaty with the Cherokee Nation, "[a] boundary is described, between nation and nation, by mutual consent. The national character of each ... is acknowledged by the other. ... This treaty . . . explicitly recogniz[es] the national character of the Cherokees."); id. at 559-60 ("We have applied [the words 'treaty' and 'nation'] to Indians, as we have applied them to the other nations of the earth. They are applied to all in the same sense."),

31 See id. at 564.

32 Id. at 566, 568.
33 See, e.g., United States v. Sioux Nation, 448 U.S. 371, 413 (1980) (noting that Lone Wolf's position, that an Indian affairs dispute is strictly a "political matter, not amenable to judicial review ...., has long since been discredited in takings cases").

34 Coben's Handbook, supra note 15, at 231 (footnote omitted) (quoting United States $v$. Wheeler, 435 U.S. 313, 322-23 (1978)).

35 See, e.g., Frank Pommersheim, "Our Federalism" in the Context of Federal Courts and Tribal Courts: An Open Letter to the Federal Courts' Teaching and Scholarly Community, 71 U. Colo. L. Rev. 123 (2000); Philip S. Frickey, A Common Law for Our Age of Colonialism: The Judicial Divestiture of Indian Tribal Autbority Over Nonmembers, 109 Yale L. J. 1 (1999), David H. Getches, Conquering the Cultural Frontier: The New Subjectivism of the Supreme Court in Indian Law, 84 Calif. L. Rev. 1573 (1996); Ralph W. Johnson and Berrie Martinis, Chief Justice Rebnquist and the Indian Cases, 16 Pub. Land L. Rev. 1 (1995); Judith V. Royster, The Legacy of Allotment, 27 Ariz. St. L. J. 1 (1995).

36118 U.S. 375 (1886). See supra notes 26-29 and accompanying text.

37435 U.S. 191, 212 (1978).

38 Id. at 206.

39 United States v. Wheeler, 435 U.S. 313, 326 (1978) (adverting to Oliphant's holding in discussing "[t]he areas in which . . implicit divestiture of [tribal] sovereignty has been held to have occurred").

40 Oliphant, 435 U.S. at 208 (quoting Oliphant v. Schiele, 544 F. 2d 1007, 1009 (1976) (decision below) (emphasis added by the Supreme Court)).

41 Id. at 203, 208-12. 
42495 U.S. 676, 685 (1990).

43 Id. at 688.

44 Id. at 685.

45 See supra note 23.

46 See 25 U.S.C. $\$ 1301$ (2) (directing that the term "'powers of selfgovernment' ... means the inherent power of Indian tribes, hereby recognized and affirmed, to exercise criminal jurisdiction over all Indians").

47 Joint Explanatory Statement of the Committee on Conference, H.R. Rep. No. 102-261, at 3 (1991), reprinted in 137 Cong. Rec. 27,041 (1991).

48 Limited intrusions on tribes' inherent powers of criminal jurisdiction also resulted from enactment of Public Law 280 in 1953 and the Indian Civil Rights Act (ICRA) in 1968. See Act of Aug. 15, 1953, ch. 505, 67 Stat. 588 (codified as amended at 18 U.S.C. $\$ 1162,25$ U.S.C. $\$ \$ 1321-1326,28$ U.S.C. $\S \S 1360,1360$ note); 25 U.S.C. $\S 1302$. In two important decisions of the modern era, the Supreme Court narrowly construed these statutes to minimize their deleterious impacts on tribal sovereignty. See Bryan v. Itasca County, 426 U.S. 373 (1976) (narrowly construing Public Law 280); Santa Clara Pueblo v. Martinez, 436 U.S. 49 (1978) (narrowly construing ICRA); see also Coben's Handbook, supra note 15 , at 243-44 (discussing Bryan and Martinez); infra text accompanying notes 56-58 (discussing Martinez).

49 See, e.g., South Dakota v. Bourland, 508 U.S. 679 (1993) (purporting to discern congressional intent to divest Tribe of power to regulate hunting and fishing by nonmembers in statue taking reservation lands for federal dam project but silent on tribal regulatory jurisdiction, and refusing to consider whether such jurisdiction is re- tained under Montana's exceptions to "implicit divestiture" of tribal sovereignty); Montana $v$. United States, 450 U.S. 544 (1981) (holding, inter alia, that Indian tribes have no inherent legislative power to regulate the conduct of nonIndians on non-Indian fee lands within reservation boundaries unless such regulation addresses "activities of nonmembers who enter consensual relationships with the tribe or its members" or that "threatens or has some direct effect on the political integrity, the economic security, or the health or welfare of the tribe"); Wasbington v. Confederated Tribes of the Colville Indian Reservation, 447 U.S. 134 (1980) (upholding a state tax on cigarette sales to non-Indians at on-reservation smokeshops, and an ancillary requirement that smokeshop operators keep detailed sales records for the state, as not impermissibly invasive of inherent tribal legislative power).

50358 U.S. 217 (1959).

51 Id. at 219, 223.

52424 U.S. 382 (1976).

53 Id. at 383.

54 Id. at 386-88.

55 Id. at 389.

56436 U.S. 49 (1978).

57 See id. at 72.

58 Id. at 64-65 (citations and footnotes omitted).

59471 U.S. 844 (1985).

60480 U.S. 9 (1987).

61 See National Farmers, 471 U.S. at 856-57.

62 Id. at 855-56 (footnotes omitted).

63480 U.S. 9 (1987).

64 See id. at 16. 
65 Id. at 18 (citations omitted).

66520 U.S. 438, 442 (1997).

67 Id. at 442

68 See id. at 445-53.

69 Id. at 445

70 See 450 U.S. 544, 564 (1981) ("[E]xercise of tribal power beyond what is necessary to protect tribal self-government or to control internal relations is inconsistent with the dependent status of the tribes, and so cannot survive without express congressional delegation.").

71 Id. at 565, quoted in Strate, 520 U.S. at $445-46$.

72 See Strate, 520 U.S. at 454-56.

73 Montana, 450 U.S. at 565-66, quoted in Strate, 520 U.S. at 456-57.

74 Strate, 520 U.S. at 457 (quoting A-1 Contractors v. Strate, 76 F. 3d 930, 940 (1996) (decision below)).

75 Id. at 457-58.

76 Id. at 459.

77 Id. (quoting Williams v. Lee, 358 U.S. 217,220 (1959)).

78 Oliphantv. Suquamish Tribe, 435 U.S. 191, 206 (1978); supra text accompanying note 38 .

79 See supra text accompanying notes 50-65.

80 Under Article III of the United States Constitution, federal judicial power extends only to "Cases" and "Controversies," U.S. Const. art. III, § 2, cl. 1. Strate was a "Case" strictly about the power of tribal courts to adjudicate a civil dispute among non-Indians only. See Strate, 520 U.S. at 443 ("Neither [tribal court plaintiff] nor [tribal court defendant] is . . . an Indian."). Because there was no "Case" or
"Controversy" in the Strate litigation implicating tribes' inherent power to adjudicate civil claims involving nonmember Indians, the federal courts, including the Supreme Court, lacked constitutional power to render a decision in the case limiting tribal jurisdiction over nonmember Indians. The Strate Court's use of the term "nonmembers" in attempting to state the case's holding therefore must be interpreted strictly to mean "non-Indian nonmembers" to avoid the obvious constitutional problem of a federal court purporting to decide a legal issue not before the court in the "Case" at bar.

81 See 25 U.S.C. $\$ 1301(2)$. Although $\S 1301$ (2) expressly recognizes and affirms tribes' inherent powers "to exercise criminal jurisdiction over all Indians," id. (emphasis added), in legislatively overriding Duro, Congress effectively displaced the Court's misguided views relating generally to the historic and ongoing exercise of inherent tribal authority over "all Indians." This, in turn, suggests that in addition to the constitutionality question noted supra at note 80 and accompanying text, the Strate Court was without power to exhume-even in a case addressing tribes' inherent civil powers-Duro's erroneous rationale for finding inherent tribal authority over nonmember Indians "implicitly divested" after Congress overrode that rationale with a statute in derogation of the Court's common law judgment in 1991.

82495 U.S. 676, 685 (1990). For a discussion of Duro and its aftermath, see supra notes $42-47$ and accompanying text.

83 See supra text accompanying notes 50-65.

84 See Strate, 520 U.S. at 453 ("Subject to controlling provisions in treaties and statutes, and the two exceptions identified in Montana, 
the civil authority of Indian tribes and their courts with respect to non-Indian fee lands generally 'do[es] not extend to the activities of nonmembers of the tribe."') (alteration in original) (citation omitted).

85 See supra notes $80-81$ and accompanying text.

8618 U.S.C. § 1151.

87 Coben's Handbook, supra note 15 , at 27 (footnotes omitted).

88420 U.S. 425 (1975).

89 Id. at 456 (reprinting Act of March 3, 1891, 26 Stat. 1035, as appendix to opinion of the Court); see also id. at 427-28 (holding "that the 1891 Act terminated the Lake Traverse Reservation").

90 Id. at 461 (Douglas, J., dissenting).

91 Id. at 447 .

92 Id. at 464 (Douglas, J., dissenting).

93 Id. at 466 (Douglas, J., dissenting).

94 See South Dakota v. Yankton Sioux Tribe, 522 U.S. 329 (1998) (diminishing the Yankton Sioux Reservation); Hagen v. Utab, 510 U.S. 399 (1994) (diminishing the Uintah Valley Reservation), Rosebud Sioux Tribe v. Kneip (1977) (diminishing the Rosebud Reservation). In only one diminishment/disestablishment case decided since DeCoteau did the Supreme Court conclude that an Indian reservation's boundaries were unaffected by a "surplus land" statute alleged to have altered those boundaries. See Solem v. Bartlett, 465 U.S. 463 (1983) (holding that the Cheyenne River Act of 1908 did not diminish the Cheyenne River Sioux Reservation in South Dakota). However, despite the correctness of its holding, the Solem Court in dicta exacerbated the diminishment/disestablishment doctrine by forging a judicial license to consider factors unrelated to the meaning of the particular statute in reaching the conclusion that an Indian reservation has been "de facto" diminished. See id. at 463 ("On a more pragmatic level, we have recognized that who actually moves onto opened reservation lands is also relevant to deciding whether a surplus land Act diminished a reservation. Where nonIndian settlers flooded into the opened portion of a reservation and the area has long since lost its Indian character, we have acknowledged that de facto, if not de jure, diminishment may have occurred.").

95 See supra text following note 87; see also Coben's Handbook, supra note 15, at 221 ("Since Congress is exercising a trust responsibility when dealing with Indians, courts presume that Congress' intent toward them is benevolent and have developed canons of construction that treaties and other federal action should when possible be read as protecting Indian rights and in a manner favorable to Indians.").

96510 U.S. at 424 (Blackmun, J., dissenting) (citation omitted).

97 In the recent case of Alaska v. Native Village of Venetie Tribal Government, 522 U.S. 520 (1998), the Supreme Court expanded its anti-tribal methodology of statutory interpretation beyond the context of the diminishment/disestablishment of Indian reservations. In Venetie, the Court addressed the question of whether 44 million acres of land in Alaska secured to Alaska Natives by the 1971 Alaska Native Claims Settlement Act (ANCSA) constitute "Indian country" by virtue of Congress's statutory inclusion of "dependent Indian communities" within the meaning of "Indian country," 18 U.S.C. § $1151(\mathrm{~b}){ }_{i}$ see supra text accompanying note 86 . The $\mathrm{Su}$ preme Court reversed the Ninth 
Circuit Court of Appeals' decision that the land in question is Indian country, rejecting the Ninth Circuit's use of a balancing test protective of Indian rights in interpreting the meaning of the statutory term "dependent Indian communities" and adopting instead the view that by enacting ANCSA, Congress intended to leave the tribes of Alaska "'sovereigns without territorial reach.'" Venetie, 522 U.S. at 523, 525-26, 531-32 n.7 (quoting Native Village of Venetie Tribal Government v. Alaska, 101 F.3d 1286, 1303 (1996) (case below) (Fernandez, J., dissenting)). The Venetie decision is, of course, additional evidence of the Supreme Court's antitribal activism in statutory construction bearing on the meaning of "Indian country."

98 See supra notes 59-82 and accompanying text.

99 See Strate v. A-1 Contractors, 520 U.S. 438, 448-53 (1997) (validating tribal court exhaustion requirement as "a prudential rule" (quoting Iowa Mutual Insurance Co. v. LaPlante, 480 U.S. 9, 20 n. 14 (1987))).

100 National Farmers Union Insurance Cos. v. Crow Tribe, 471 U.S. $845,856-57$ (1985) (footnotes omitted).

101 Iowa Mutual, 480 U.S. at 16-17 (citations omitted) (quoting $\mathrm{Na}$ tional Farmers, 471 U.S. at 857).

102 Strate, 520 U.S. at 450 (citation omitted) (quoting Iowa Mutual, 480 U.S. at 857) (alteration made by Strate).

103 See id. at 448 ("Both [National Farmers and Iowa Mutual] describe an exhaustion rule allowing tribal courts initially to respond to an invocation of their jurisdiction; neither establishes tribal-court adjudicatory authority, even over the lawsuits involved in those cases."); see also supra notes $68-70$ and accompanying text.
104 National Farmers, 471 U.S. at 856 ; supra text accompanying note 100 .

105526 U.S. 473 (1999).

106 See id. at 476-79. As used here, the abbreviation "nuclear tort" refers to the Price-Anderson Act's conversion to a federal cause of action of "any legal liability arising out of or resulting from a nuclear incident or precautionary evacuation." 42 U.S.C. $\$ 2014(\mathrm{w})$, quoted in Neztsosie, 526 U.S. at 476.

107 See Neztsosie, 526 U.S. at 478, $482-83$ \& nn. $4-5$

108 See id. at $476,485,487-88$.

109 Id. at 484 (quoting 42 U.S.C. § $2210(n)(2)$.

110 Id. at 485 n.7.

111 Id. at 485-86 n.7 (citation omitted).

112 Id. at 483

113 Id. at 486

114 Id. at 484

115 National Farmers Union Insurance Cos. v. Crow Tribe, 471 U.S. $845,856-57$ (1985); supra text accompanying note 100 .

116 Neztsosie, 526 U.S. at 487. Justice Souter, writing for the unanimous Neztsosie Court, made this enigmatic statement in explaining the Court's decision to ignore the conventional textual canon of construction expressio unius est excusio alterius_-"expression of one thing shows the exclusion of others"in concluding that the PriceAnderson Act's express provision of removal from state courts does not imply that Congress intended to leave the jurisdiction of tribal courts unaffected. See id. However, the statement also implies a complete disregard of Congress's general solicitude for Indian rights in the Court's interpretation of the act's silence on tribal courts. 
117 Cf. Iowa Mutual Insurance Co. v. LaPlante, 480 U.S. 9, 18 (1987)

("Civil jurisdiction over ... activities [of non-Indians on reservation lands] presumptively lies in the tribal courts unless affirmatively limited by a specific treaty provision or federal statute."); supra text accompanying note 65 .

118 A surprisingly encouraging remark appears in a footnote to the unanimous Neztsosie opinion. After explaining why the Ninth Circuit for "institutional" reasons should not have addressed the merits of the district court's nonappealed holding that the Navajo Tribal Courts had no subject matter jurisdiction over Price-Anderson Act claims, see Neztsosie, 526 U.S. at 479-82, the Supreme Court nevertheless cast doubt on the assumption that a deprival of tribal court jurisdiction could be justified on the basis of Strate: "Strate dealt with claims against nonmembers arising on state highways, and 'express[ed] no view on the governing law or proper forum when an accident occurs on a tribal road within a reservation.' By contrast, the events in question here occurred on tribal lands." Id. at 482 n. 4 (citations omitted) (quoting Strate v. A-1 Contractors, 520 U.S. 438,442 (1997) (alteration in original). Although this comment suggests that the Court would not expand Strate to find tribal adjudicatory jurisdiction over PriceAnderson Act claims "implicitly divested," a further dictum implies that the Court might find tribal jurisdiction divested on the basis of some other theory: "[O]ur view of the inappropriateness of applying tribal exhaustion suggests that, notwithstanding the silence of the Price-Anderson Act with respect to tribal courts, the exercise of tribal jurisdiction over claims found to fall within the Act once a defendant has sought a federal forum would be anoma- lous at best." Id. at 483 n. 5 (citation omitted).

119 Tribal courts must enforce federal court judgments pursuant to the Supremacy Clause of the United States Constitution. See U.S. Const. art. VI, cl. 2.

120 This presumes, of course, that the particular tribal court has been granted tribal authority to enact such rules.

121 See, e.g., Alden v. Maine, 527 U.S. 706 (1999) (holding that Congress has no power to abrogate state sovereign immunity by making states answer federal-question suits in state courts); Idabo v. Coeur d'Alene Tribe, 521 U.S. 261 (1997) (holding that suits brought by Indian tribes against state officials alleging violations of tribes' federally protected rights to on-reservation submerged lands and seeking only prospective relief nevertheless do not qualify for federal court jurisdiction pursuant to the Ex parte Young exception to state sovereign immunity); Seminole Tribe v. Florida, 517 U.S. 44 (1996) (holding that Congress has no power under Article I of the Constitution to abrogate state sovereign immunity by making states answer federalquestion suits in federal court, including suits brought by Indian tribes to vindicate the tribes' federally protected rights).

122 See the following sections: "Great Sioux Nation Law and Culture Journal," "Great Sioux Nation Legislative Drafting Project," Great Sioux Nation Constitution Revision Project," and "Great Sioux Nation Law and Economic Development Project."

123 See Act of June 18, 1934, ch. 576, $\S 17,48$ Stat. 988 (codified as amended at 25 U.S.C. § 477).

124 See the section "Jurisdiction." 